\title{
Other proteins involved in Parkinson's disease and related disorders
}

Fernando Cardona ${ }^{1,2^{*}}$ and Jordi Pérez-Tur ${ }^{1,2,3^{*}}$

${ }^{1}$ Unitat de Genètica Molecular. Institut de Biomedicina de València (C.S.I.C.), Spain.

${ }^{2}$ Ciberned. Spain.

${ }^{3}$ Unidad Mixta de Neurología y Genética Molecular. Instituto de Investigación Sanitaria

La Fe. València, Spain.

*Correspondence to Fernando Cardona (cardona@ibv.csic.es) and Jordi Pérez-Tur (jpereztur@ibv.csic.es). Instituto de Biomedicina de Valencia, Consejo Superior de Investigaciones Científicas (IBV-CSIC). Calle Jaime Roig 11, Valencia E46010, Spain.

\begin{abstract}
In order to explain the molecular causes of Parkinson's Disease (PD) it is important to understand the effect that mutations described as causative of the disease have at the functional level. In this special issue, several authors have been reviewing the effects in PD and other parkinsonisms of mutations described in LRRK2, $\alpha$-synuclein, PINK1Parkin-DJ-1, UCHL1, ATP13A2, GBA, VPS35, FBOX7 and HTRA2. In this review, we compile the knowledge about other proteins with a more general role in neurodegenerative diseases (MAPT) or for which less data is available due to its recent discovery (EIF4G1, DNAJC13), the lack of structural or functional data (as for PLA2G6 or DNAJC6), or even their doubtful association with the disease (as for GIGYF2, SYNJ1 and SPR). Also the cellular pathways involved in this disease are reviewed, with the goal of having an overview of the effects on the proteins and its possible role in the disease. This knowledge could also serve as the basis for designing tools that may potentially be used as a treatment for the disease, such as inhibitory or activating molecules, as well as other involved in regulating the half-life of the proteins involved.
\end{abstract}

Keywords: SPR, GIGYF2, PLA2G6, eIF4G1, DNAJC6, SYNJ1, DNAJC13, PARK10, PARK16, MAPT 


\section{Parkinson's disease and related disorders}

Parkinson's disease (OMIM\#168600, PD) is a neurodegenerative disorder characterized by the death of dopaminergic neurons in the substantia nigra, frequently accompanied by Lewy Body inclusions (LB). The cardinal motor symptoms are asymmetric resting tremor, bradykinesia, rigidity and postural instability [1]. Other motor symptoms are gait and posture disturbances, festination, speech and swallowing alterations, mask-like face expression or small handwriting [2]. Also, neuropsychiatric disturbances could appear, from mild to severe, including disorders of speech, cognition, mood, behavior and thought. Frequent non-motor symptoms include drowsiness, disturbances in REM sleep or insomnia [1]. On the other hand, alterations in the autonomic nervous system can produce orthostatic hypotension, urinary incontinence, oily skin and excessive sweating, constipation, altered sexual function and gastric dysmotility [3]. The disease is also related to several eye and vision alterations such as low blink rate, dry eyes, difficulties in directing gaze upward, deficient ocular pursuit and saccadic movements, and blurred or double vision [4]. Abnormal sensorial traits may include altered sense of smell, pain or paresthesia. All, or most, of these non motor symptoms may occur years before the motor symptoms of the disease, so are useful for early diagnosis. While depression is the most common psychiatric symptom, slow thinking and behavioral problems may occur, commonly with dementia in advanced stages of the disease [1].

The main motor symptoms are collectively called "parkinsonian syndrome", and several diseases which present any cardinal symptom are refered to as parkinsonisms, presenting also features that distinguish them from PD. They include multiple system atrophy (OMIM\# 146500, MSA), progressive supranuclear palsy (OMIM\# 601104, PSP), Parkinson-dementia syndrome (OMIM \#260540, PDS), frontotemporal dementia with parkinsonism linked to chromosome 17 (OMIM\# \#600274, FTDP-17), Dystoniaparkinsonism (OMIM\# 612953, DP) and dementia with Lewy bodies (OMIM\# 127750, DLB) [5].

\section{Proteins involved in Parkinson's disease and related disorders}

To date, 20 PARK loci have been described taking into account that PARK4 was demonstrated to be, in fact, PARK1 (Table 1)[6-9]. The effects of the mutations at the protein and cellular levels are widely discussed in this thematic issue for PARK1, PARK2, PARK5, PARK6, PARK7, PARK8, PARK9, PARK13, PARK17 and GBA, a PD risk factor. For other $l o c i$, the gene responsible of the association has not been definitively assigned (for instance PARK10, PARK12 or PARK16). In addition, other risk factors have been described, as is the case for $M A P T$. In this chapter, we present information about the proteins coded by the PARK genes not described in the other chapters. In addition, we include here the association of MAPT with PD due to the fact that it has been consistently shown in several populations. For all these proteins, we summarize some data about the effect of the mutations in terms of its molecular and cellular effects, and how they help us in trying to understand the molecular basis of this disease. 


\section{SPR (PARK3)}

Gasser et al. (1998) mapped PARK3 (OMIM\#612716) to the 2p13 region (Table 1)[69], which comprises two candidate genes, $S P R$ and $H T R A 2$, the latter also proposed, with some controversy [10], as related to PD in the PARK13 locus [11]. Due to this result, although HTRA2 could be the prime candidate to explain the association of PD with PARK3, it was excluded from this locus by West and colleagues [12]. Subsequent evidence had shown linkage with familial Autosomal Dominant (AD) Late Onset (LO) PD as well as association with sporadic PD to SPR (2p13.2, OMIM\#182125) [12-15]. However, no PD-related mutations have been found in this gene, whereas in doparesponsive dystonia, a disease that sometimes includes parkinsonism [16-18] several mutations have been described in this gene. None of these mutations are in residues described as important for the function of the protein.

Sepiapterin reductase (SPR) catalyzes the final step of biosynthesis of tetrahydrobiopterin (BH4), an essential cofactor for the metabolism of phenylalanine and the nitric oxide production, melatonin, serotonin, norepinephrine, epinephrine and dopamine. BH4 deficiency is clearly associated with diverse neurologic diseases [19]. The enzyme is an aldo-keto reductase that catalyzes the NADPH-dependent reduction of carbonyl species. The analysis of conserved domains using the Conserved Domain Database (CDD: http://www.ncbi.nlm.nih.gov/Structure/cdd/wrpsb.cgi)[20] describes the protein as a 261 amino acids dimeric protein, with the catalytic domain comprising almost all the protein (Figure 1). The short-chain dehydrogenase domain includes the region from amino acids 9 to 187, and the active site is in residues 127,157,170 and 174. The binding substrate pocket lays in residues 157 and 158, and there are several $\mathrm{NADP}^{+}$binding sites along the protein.

Yang et al. (2006)[21] found that the Spr knock out (KO) mouse displayed altered pterin profiles and very low levels of dopamine, serotonin and norepinephrine. This model exhibits phenylketonuria, dwarfism, and altered movement, and supplementation with BH4 and neurotransmitter precursors rescue dwarfism and phenylalanine metabolism. The phenotypic characteristics, as well as the symptoms and their treatment, present a high level of similarity with SPR-deficient patients.

In our opinion the role for SPR in PD is dubious, since the animal model does not reproduce totally the disease, and the enzyme has a very general role in neurotransmitter synthesis. So, one possibility is that SPR has a role in dopa-responsive DP but not in PD. Moreover, the differential diagnosis between these two diseases is not always easy.

\section{GIGYF2 (PARK11)}

The GIGYF2 gene (2q37.1, OMIM\#612003) has been proposed as the gene responsible of the association of the PARK11 locus with LO-AD-PD (OMIM\#607688) [22] (Table 1)[6-9], but this association has been controversial [23-26]. In PD-affected members of 12 unrelated families, Lautier et al., (2008) [22] described 7 heterozygous mutations in this protein (p.N56S, p.T112A, p.S335T, p.N457T, p.D606E, p.I278V and p.V1242I) 
showing segregation of mutations with disease in the families for which additional samples were available, four of the 7. However, Nichols et al., (2009) [23] did not identify 5 of these 7 variants in 96 patients with PD linked to chromosome $2 q$ nor in a sample of 566 PD families. Of the remaining two, one variant (p.N56S) was found in 2 families and showed incomplete penetrance whereas the other variant found in 1 additional family (p.N457T) was demonstrated not to segregate with the disorder. Later, Zimprich et al., (2009) [24] found the p.N56S variant in 1 of 669 PD probands and in 1 of 1,051 non affected individuals. The patient with PD had a sister with PD without this variant. In addition, in an Egyptian cohort, the p.N457T variant was found in 1 patient but not in 50 controls and was also found in 3 controls of European origin. Bras et al., (2009) [25] found also the p.N457T variant in a Portuguese control individual. On their turn, Tan et al., (2009) [27] identified 4 different heterozygous mutations in GIGYF2 (p.A2G, p.K421R, p.I768V and p.H1304L) in 7 of 450 Asian patients with PD, and not in 400 controls. None of the mutations reported by Lautier et al., (2008) [22] were found in this study [27]. In a recent paper, Ruiz-Martinez et al. (2015) [28] described a small pedigree with LO-PD and cognitive impairment with a change in GIGYF2 (p.R610G) supporting a role of this gene in PD. Nevertheless, this substitution seems to be privative of the Basque population and not related to PD (Cardona, Andreu et al. manuscript in preparation).

With all this genetic information, the results obtained by Lautier et al. (2008)[22] should be interpreted with caution, and more thorough replication studies should be completed to conclude if any of the proposed genetic variants are truly pathogenic.

At the protein level, according to CDD (Figure 1), GIGYF2 contains a Smy2-type GYF domain in the region from residue 533 to 584, including the GRB10-binding domain (amino acids 547 to 563) and also a conserved Gly-Tyr-Phe motif (amino acids 578, 583 and 584) involved, in other proteins, in proline-binding. The tridimensional structure of this domain has been solved for other human proteins (Cd2bp2) and for Saccharomyces cerevisiae. Also, according to Uniprot (http://www.uniprot.org/), [9] several residues have been described as targets for translational modifications such as acetylation and phosphorylation. Other authors have proposed that this domain interacts with proteins involved in transport processes, in those involving mRNA translation regulation, and probably is present in stress granules [29]. It is remarkable that, as described by several authors, almost all of the substitutions proposed as pathogenic are in very conserved positions. Even though the protein is very conserved across evolution (Suppl. Fig. 1), especially in the region from residues 508 to 655 (GYF domain), although the vast majority of mutations are outside this latter domain.

In PD affected brains, GIGYF2 did not colocalise with Lewy bodies [30]. Functional studies show that it is present in endosomes, and point to an important role in signal transduction, specifically in the insulin-like growth factor-1 (IGF-1) and the extracellular signal regulated kinase (ERK) 1/2 pathways, with GIGYF2 expression levels affecting the phosphorylation of these proteins [30,31]. 
Despite the lack of association in some genetic studies, murine models suggest the involvement of this protein in age-related neurodegeneration and motor dysfunction, with $\alpha$-synuclein positive neuritic plaques in the brainstem and cerebellum, but no in the substantia nigra and rare LB-like inclusions [31]. Moreover, a recent study in Asian populations [32] and a meta-analysis [33] suggest a positive association with PD, so it is yet unclear if it is a causative gene, a risk factor or it is not related.

\section{PLA2G6 (PARK14)}

Dystonia-parkinsonism (DP) (OMIM\# 612953) linked to PLA2G6 (22q13.1, OMIM\# 603604) is an Autosomal Recessive (AR) Adult Onset (AO) neurodegenerative disorder (Table 1)[6-9]. Mutations in this gene cause also AR neurodegeneration with brain iron accumulation (NBIA, OMIM\#610217), and infantile neuroaxonal dystrophy 1 (OMIM\#256600) [34, 35].

Paisan-Ruiz et al. (2009) [35] described 2 unrelated families with AO-DP with 2 different homozygous mutations in the catalytic domain of the protein (p.R741Q and p.R747W). In JO-parkinsonism, Yoshino et al. (2010) [36] identified compound heterozygous mutations (p.Q452X/p.R635Q) in 2 Japanese sibs and the p.F72L/p.R635Q mutations in a third unrelated individual. Haplotype analysis showed a founder effect for the p.R635Q mutation. Progenitors with heterozygous mutations had no signs of the disorder. Malaguti et al. (2015) [37] found that the p.A516V mutation, within the catalytic domain and near the active site, causes also DP in homozygosis. In a Chinese patient with Early Onset (EO) PD, born of a consanguineous marriage, Shi et al. (2011) [38] identified a homozygous mutation in the ankyrin-repeats domain (p.D331Y), causing a 70\% of reduction in enzyme activity. However, other authors found that NBIA mutations severely decrease enzyme function, while other mutations causing DP did not change the activity or even increased it [39]. Xie et al. (2015) [40] found also the p.D331Y mutation in two patients with AR-EO-PD, confirming the role of this substitution in the disease.

PLA2G6 is a calcium-independent type A2 phospholipase (PLA2) with 806 amino acids that catalyze the hydrolysis of the sn-2 acyl-ester bonds in phospholipids, producing the removal of arachidonic acid, regulated by responses to dopaminergic signaling, and other fatty acids [41]. According to CDD (Figure 1) the protein presents an ankyrinrepeats domain in the region comprising residues from 103 to 403. The catalytic domain is a patatin-like phospholipase, present in the region 480-793, with the active site comprising amino acids from 517 to 521 .

Although there is not an experimentally determined 3D structure for this protein, several coincident homology models are available for the ankyrin-repeats domain at the Protein Model Portal (http://www.proteinmodelportal.org/)[42]. Using one of these models, we predicted the loss of negative charge in the electrostatic surface exposed to the solvent caused by p.D331Y (Suppl. Fig. 2). 
Malik et al. (2008) [43] found that KO mice present age-dependent neurologic impairment in movement tests. Neuropathologic analysis of the brain of these mice showed numerous spheroids, similar to those present in infantile neuroaxonal dystrophy, which stained strongly with anti-ubiquitin antibodies. These KO mice present also neuroaxonal dystrophy with mitochondrial inner-membrane damage, causing axon terminal degeneration and rupture of the presynaptic membranes [44]. Since has been shown that loss of PLA2G6 leads to elevated mitochondrial lipid peroxidation and mitochondrial dysfunction in flies and human fibroblasts, the mitochondria is the most probable organelle affected for these mutations, as well as a potential therapeutic target [45].

\section{eIF4G1 (PARK18)}

In affected members of a big family with AD-LO-PD (OMIM\#614251), Chartier-Harlin et al. (2011) [46] identified the heterozygous mutation p.R1205H in eIF4G1 (3q27.1, OMIM\# 600495) using genome-wide linkage analysis. By whole-exome sequencing in 213 patients with PD, Nuytemans et al. (2013) [47] identified 1 patient who carried a heterozygous p.R1205H variant that segregated with the disease.

However, this variant was also found in an asymptomatic 86-year-old family member indicating, at best, incomplete penetrance [47]. Nevertheless Nichols et al. provided evidence refuting its role in classical idiopathic PD [48].

After that, EIF4G1 was analyzed in 95 patients with AD parkinsonism and 130 cases of Lewy Body Disease (LBD), identifying 4 additional different mutations in 2 PD and 2 LBD patients. Then, these 4 variants (p.A502V, p.G686C, p.S1164R and p.R1197W) were tested in a case-control study of 4,483 PD patients and 3,865 controls: two of the variants were found in 3 additional patients, 2 with p.A502V and 1 with a p.G686C substitution.

The initiation factors of the eIF4 group catalyze the recognition of the cap and unrolled secondary mRNA structure in the initiation of translation. eIF4G (Table 1)[6-9], is a $154-\mathrm{kD}$ protein that forms complexes with other EIF4 proteins. The complex comprising eIF4A, eIF4E and eIF4G (eIF4), lead the recruitment of mRNA to the ribosome, which is the limiting step for translation [49].

eIF4G1 contains, in the N-terminal region, a binding site for eIF4E (W2 eIF4G1-like), whereas the central third of eIF4G1 contains an eIF3-binding region (MA3) and an eIF4A-binding domain (MIF4G) (Figure 1). [50]. The structure of the C-terminal portion of the human protein has been solved [51], and also a part of the yeast homologue protein in complex with eIF4A [52]. The N-terminal region of eIF4G1 binds polyA-binding protein [53]. The analysis with CDD (Figure 1) showed that W2 eIF4G1-like domain comprises residues from 1455 to 1557, MIF4G domain from 768 to 993 and MA3 domain from 1249 to 1361 . With lower probability the tool identifies 2 additional domains: Med15 (co-activator of the transcription factor SREBP) comprising residues 24 to 459 and DUF1777 (unknown function, putative nucleic acid binding 
domain) in residues 1144 to 1259 . Regarding the described mutations causing PD, p.R1205H would be in the domain of unknown function, and p.A502V and p.G686C would be out of the defined domains. In any case, the domains of the human protein containing these mutations are neither solved nor found in the yeast homologue. Thus, structural and functional studies of these parts of the protein are necessary to understand the molecular mechanisms that cause the disease linked to this gene.

Chartier-Harlin et al. (2011) [46] found that the p.R1205H and p.A502V substitutions affect the formation of the translation initiation complex. These results are compatible with a dominant-negative effect of these mutations, as well as the age-dependent neurodegeneration. Hydroperoxide insult caused an important alteration of the mitochondrial membrane potential, comparing cells expressing the mutations with those expressing the wild-type protein. These authors postulated that these amino acid changes are difficulting the ability to respond to stress, probably by changes in the translation mRNAs essential to survive to the stress. It is also remarkable that eIF4G1 interacts genetically with VPS35 and $\alpha$-synuclein [54].

On the other hand, a conditional transgenic mice, expressing the p.R1205H or p.A502V variants under the control of a highly expressed promoter in brain, the CAMKK2 promoter, shows behavioral deficits not seen in wild-type animals together with progressive degeneration of dopaminergic neurons in the substantia nigra [55].

Therefore, in view of these biological evidences, the reported genetic linkage between familial PD and EIF4G1 can be restricted to an atypical form. In effect, in the first work describing mutations in EIF4G1 [46] the evolution of the disease was very slow compared to classical PD, and consistent with a limited loss of dopaminergic neurons similar to that observed in 12 month-old eIF4G1 transgenic mice and also with the neuronal loss observed in older mice (30 to $40 \%$ loss in 24 month-old mice) [55].

\section{DNAJC6 (PARK19)}

Homozygous mutations in DNAJC6 cause PARK19 linked PD (OMIM\#615528), characterized by Autosomal Recessive (AR) and Juvenile Onset (JO) and sometimes additional neurologic features, such as mental retardation or seizure [56, 57] (Table 1)[6-9]. Koroglu et al. (2013) identified a homozygous p.Q734X substitution in 4 patients from highly consanguineous Turkish families with JO-PD and mental retardation [56]. In 2 consanguineous Palestinian brothers with JO-PD, Edvardson et al. (2012) identified a homozygous loss-of-function mutation in DNAJC6 (1p31.3, OMIM\# 608375) [57]. The mutation results in the generation of 2 misspliced transcripts: an inframe exon 7-skipped transcript lacking residues from 268 to 328, (lacking almost all the Pten-C2 domain, Figure 1) and an out-of-frame transcript with an insertion of the last 91 nucleotides of intron 6 resulting in the addition of 8 residues before a stop codon (lacking both functional domains). The normally spliced transcript was undetectable, and the mutant transcripts were unstable, consistent with a loss of function. 
DNAJC6 presents abundant expression in several human brain regions (cerebellum, corpus callosum, cortex, striatum, brainstem, pons, putamen, spinal cord) including substantia nigra, and very low expression in nonneural tissues [56]. This gene encodes the HSP40 Auxilin, a protein of 970 amino acids expressed in neurons and involved in the clathrin-mediated endocytosis pathway. This protein presents similarity with the ubiquitously expressed protein GAK, acting both as cochaperones in the HSC70dependent clathrin removing of vesicles [58]. It is also remarkable the possible association of GAK as risk factor for LO-PD [59-61], probably by interaction with LRRK2 [62]. DNAJC6 belongs to the evolutionarily conserved DNAJ/HSP40 family, which regulate chaperone activity stimulating the ATPase activity of Hsp70, with functions in protein translation, folding, unfolding, translocation and degradation. According to CDD, the protein presents 2 conserved domains (Figure 1). The PTENC2-like domain, which in PTEN plays a role in membrane binding and associates with the N-terminal phosphatase domain DSPc, lies between residues from 283 to 421, suggesting that the $\mathrm{C} 2$ domain positions the catalytic part of the protein onto the membrane [63]. In the region from amino acids 918 to 963 lies the DnaJ domain or Jdomain. This domain comprises the motifs involved in the interaction with Hsp70 (residues from 934 to 956) [64, 65].

The fact that DNAJC6 plays a role in clathrin-mediated endocytosis suggests that a defect in the neuronal endocytic/lysosomal pathway contributes to the pathogenesis of PD. It is also notable that auxilin is selectively expressed in neurons and enriched in nerve terminals, where it plays a role in clathrin-mediated endocytosis. Also significant is that other genes mutated in PD, including RAB7L1, SNCA, SYNJ1 and LRRK2, participate in synaptic vesicle recycling, pointing to an important role of the endosomal/lysosomal pathway in PD.

Yim et al. (2010) found that Dnajc6 KO mice had a high rate of early postnatal mortality, although surviving mice have normal life span despite decreased body weight [58]. This mouse had impaired synaptic vesicle recycling and increased number of clathrin-coated vesicles, as well as impaired clathrin-mediated endocytosis of synaptic vesicles in neuronal culture. In brain tissue of Dnajc6 KO mice, Edvardson et al. (2012) did not find any histological alteration in substantia nigra nor in dopamine transporter abundance or distribution, in agreement with the lack of parkinsonism-related phenotype in mutant mice [57].

\section{SYNJ1 (PARK20)}

In 2013, Krebs et al. [66] and Quadri et al. [67] identified simultaneously the same homozygous missense mutation (p.R258Q) in SYNJ1 (PARK20, OMIM\#615530) (Table 1)[6-9] in affected brothers with AR-EO-PD in non-related consanguineous families. [66]. Perera et al. (2006) found that the 2 major isoforms were differentially recruited to clathrin-coated pits in transiently transfected COS-7 cells [68]. The ubiquitously expressed $170 \mathrm{kDa}$ isoform was present at clathrin-coated vesicles in all stages, whereas the $145 \mathrm{kDa}$ isoform, which is predominantly expressed in brain, was 
rapidly recruited at the late stage of clathrin-coated vesicle formation. Perera et al. (2006) concluded that dynamic phosphatidylinositol (PI) metabolism may be related to the lifetime of clathrin-coated vesicles [68]. The CDD database defines the catalytic PI(5)-phosphatase domain in the region from amino acid 572 to 907 (Figure 1), and the active site in the residues from 580 to 898. Also a RNA-binding domain (RRM, Figure 1 ) is present in this protein in the region from residue 932 to 1008 . A highly conserved domain in the $\mathrm{N}$-terminal region (amino acids 98 to 385) is the Syja-N domain, homologous to SacI PI-phosphatase domain of S. cerevisiae, capable of hydrolyzing PI3-phosphate (PI3P), PI-4-phosphate (PI4P) and PI-(3,5)-bisphosphate (PI(3,5)P2) to PI, whereas the 5-phosphatase domain selectively removes the phosphate group at the $5^{\prime}$ position of the inositol ring and uses $\mathrm{PI}(4,5) \mathrm{P} 2$ as its main physiological substrate [69]. This domain is also involved in the endosomal pathway in S. cerevisiae [70]. Quadri et al. (2013) also showed that SYNJ1 (21q22.11, OMIM\#604297) interacts with DNAJC6, and both proteins are involved in synaptic vesicle endocytosis [67]. These findings also suggest that defective recycling of synaptic vesicles may play a role in the neurodegeneration observed in PD.

Since the truncated protein p.Q734X (2013) [56] lacks the entire J-domain (Figure 1), its function must be obviously affected, so both co-chaperone function and Hsp70 binding should be compromised. Although the mutation p.R258Q seems not affect the functional domains described (Figure 1), functional studies indicated that the mutant protein has very reduced phosphatase activity against PI3P and PI4P, but no against $\mathrm{PI}(4,5) \mathrm{P} 2$ [66].

Several results suggest that the correct dosage of Synj1 is important for normal brain development and function in animal models. First, Voronov et al. (2008) found that the altered PI(4,5)P2 metabolism in the brain of a mouse model of Down syndrome, could be rescued overexpressing Synj1 [71]. Besides, Cremona et al. (1999) showed that mice with a disruption of Synj1 exhibits neurologic defects and died after birth [72]. In neurons of mutant animals, PI(4,5)P2 levels were increased, and clathrin-coated vesicles accumulated in the periphery of the synaptic vesicle in nerve endings. In in vitro assays, reduced enzymatic activity is well correlated with increased association of clathrin coats with liposomes [72]. These results provided evidences of the role of phosphoinositide metabolism in synaptic vesicle formation and recycling, as well as the relationship with the brain function.

\section{DNAJC13 (PARK21)}

In 2014, Vilariño-Güel et al. [73] found that mutations in DNAJC13 (3q22.1, OMIM\# 601184), segregate with the disease in a family with AD-LO-PD (OMIM\#616192).

DNAJC13 (Table 1)[6-9] encodes a 2,243 amino acid protein that belongs to the same family as DNAJC6 (PARK19). It localizes in the membrane of the endosomal system and also with a punctate pattern in the perinuclear region, playing a role in vesicle formation and endocytic trafficking $[73,74]$. Like DNAJC6, DNAJC13 contains a DnaJ homologous domain that interacts with HSC70 in an ATP-dependent manner [74]. This 
domain (amino acids from 1332 to 1348) contains the conserved his-pro-asp (HPD) motif, from amino acids from 1301 to 1354 , that is probably involved in the regulation of ATPase activity of HSC70 [75]. C-terminal end (amino acids from 1 to 243) is involved in membrane interaction [76] and a domain of unknown function (DUFF4339) is predicted by CDD in the region comprising the residues from 975 to 1020 (Figure 1).

Other mutation, p.A2057S, is probably involved in Tourette syndrome [77]. Note that none of the described mutations are located in a predicted domain (Figure 1).

Due to their role in clathrin-mediated endocytosis, DNAJC6, SYNJ1 and DNAJC13 are probably related to the disease. Moreover, DNAJC6 and DNAJC13 share also a common partner, HSC70, a well-known chaperone, which stress their interrelationship. However, when they exist, animal models do not reproduce the parkinsonian phenotype, although do show an altered autophagy, known to be related to the disease.

\section{ADDITIONAL PARK LOCI}

In addition to the proteins described so far, a few loci are still under investigation as they have been proposed to contain a gene involved in PD pathogenesis. These are:

\section{PARK10}

The PARK10 locus (1p32, OMIM\# 606852) had been linked to AD-LO-PD in several studies (Table 1) [6-9, 78, 79]. Latter analyses narrowed the associated region to genes EIF2B3 and USP24, with EIF2B3 showing stronger statistical results [80] whereas other authors found a stronger association for the ubiquitin-specific protease USP24 [81]. In addition, in other studies it was found an association to other close genes such as $H I V E P 3$, a transcriptional regulator [80], $C D C P 2$, an oxidoreductase potentially involved in cholesterol biosynthesis and electron transport [82] and the 3'UTR RNAbinding protein ELAVL4 [83-85]. In a recent work, also DAB1 was proposed as the responsible of this association [86]. In any case, no changes in any of those proteins were described in PD. In summary, although an association was described to this locus, it is still unclear the gene responsible for this association. Therefore, more genetic studies, as well as functional studies are necessary to clarify if this locus is related to these diseases and to explain the mechanism.

\section{PARK16}

Simustaneously, Sakate et al. and Simon-Sánchez et al. (2009) linked a genomic region (1q32, OMIM\# 613164) comprising the genes RAB7L1 and SLC41A1 to AD-LO-PD [87, 88] (PARK16, Table 1)[6-9]. Subsequent studies suggested that $R A B 7 L 1$ is the gene responsible of this association, with a probable interaction with $L R R K 2$ and the autophagy-endolysosomal pathway $[89,90]$. However, other authors proposed SLC41A1 (a divalent cation transporter) as candidate gene, based on functional studies of two missense variants, p.A350V [91, 92] and p.R244H [92]. In summary, although an association was narrowed to these two genes, more studies are necessary to clarify the gene responsible of the association as well as the function or the pathways involved. 
Based in the relationship between PD and vesicle traffic, $R A B 7 L 1$ is most probably gene responsible of the association of PARK16 to the disease, so is involved also in endocytosis and interacts with LRRK2 [89].

\section{MAPT}

In addition to those proteins found by mean of genetic analysis, a number of other proteins have also been involved in the ethiology of PD by association studies using candidate-gene approaches. What follows is the summary of the most relevant risk factor, in addition to GBA already treated in another chapter, MAPT.

The microtubule-associated protein tau (MAPT, 17q21.31, OMIM\#157140) assembles with tubulin into microtubules in vitro and is enriched in axons. It had been associated to several neurodegenerative diseases including PD, PSP or FTDP-17, collectively known as tauopathies (Table 1)[6-9].

In the adult brain there are 6 isoforms produced by alternative splicing [93] (Figure 2). The different isoforms (ranging from 352 to 441 amino acids in length) differ by the presence or absence of 29 or 58 amino acid in the N-terminus and a 31 amino acid repeat in the C-terminus. The latter, encoded by the alternatively spliced exon 10 , constitutes a repeat of the microtubule-binding domain. Its inclusion or exclusion results in tau isoforms with 4 (4R) and 3 (3R) of theses repeats. In brain tissue from patients, the normal 3R/4R ratio is altered. Thus, in FTDP-17, an abnormal preponderance of soluble 4R over 3R isoforms exists [94], leading to the formation of abnormal tau filaments and neurodegeneration [95]. Panda et al. (2003) noted that the high ratio of $4 \mathrm{R}$ to $3 \mathrm{R}$ isoforms cause cell death by altering normal functions in neurons, because $4 \mathrm{R}$ isoform stabilized microtubules stronger than 3R [96]. These authors suggested a model in which the expression must be regulated to produce appropriate levels of each isoform. In the $\mathrm{N}$-terminus of the protein, two other repeats are coded by exons 2 and 3 producing the $0 \mathrm{~N}, \mathrm{~N} 1$ and $\mathrm{N} 2$ isoforms depending on the number of repeats included in the protein (Figure 2).

Mutations causing familial neurodegeneration have been observed to cluster in the Cterminal part of the protein, affecting the microtubule repeats. Most of these mutations alter the 4R/3R ratio or affect its structural and functional properties, rendering the tau protein more prone to aggregation in addition to decrease microtubule assembly (e.g. p.G272V, p.delN296) [97, 98]. On the other hand, amino acid 301 seems to be a hotspot for mutations and it affects 4R isoforms [99, 100]. Whereas FTDP-17 is the most common phenotype caused by heterozygous mutations in tau, PSP or PD could also appear due to mutations in the gene, with homozygosity related to the PSP phenotype $[101,102]$.

The only mutations not found in the C-terminus region of the gene affect amino acid 5 (p.R5L/H). As with mutations in the microtubule binding domain, both $\mathrm{N}$-terminal mutations affect the microtubule assembly and affect the ability of tau to aggregate and to form fibrils [103, 104]. 
Giasson et al. (2003) demonstrated in vitro that $\alpha$-synuclein induces fibrillization of tau, and their coincubation synergistically promotes fibrillization of both proteins [105].

Both proteins are abundant in normal neurons in an unfolded conformation, but polymerize in disease. Studies in mice with $\alpha$-synuclein or tau mutations also showed inclusions of both proteins, suggesting an interaction between $\alpha$-synuclein and tau that led to the formation of these inclusions in neurodegenerative diseases. Rizzu et al. (2004) showed also that DJ-1 colocalizes within tau inclusions, losing its solubility in these inclusions [106].

De Calignon et al. (2010) observed tangles and activation of caspases in a previously described tau transgenic mice $[107,108]$. Similarly, over-expression of non-mutated 4R into wildtype animals produces tau truncation and aggregation together with caspase activation. A construct producing a caspase-cleaved tau into wildtype mice produce intracellular aggregates and the recruitment of normal endogenous tau to them. This led these authors to propose a new model in which the caspase cleaves tau to start the tangle formation, and then truncated tau recruits normal tau, misfold it and form tangles. Because these neurons did not die, De Calignon et al. (2010) suggested that tangles are structures to avoid neuronal death, and that soluble tau species, rather than fibrillar tau, are the toxic forms that cause neurodegeneration [107].

The role of MAPT as risk factor for this diseases is well known and demonstrated, although the mutations involved in this association are not well described. The presence of the haplotype $\mathrm{H} 1$ clearly increases the risk for the disease [109], but how this genetic association translates to the function of the protein is still unclear.

\section{CONCLUDING REMARKS}

In this chapter were reviewed the PARK loci not covered previously in this special issue. In order to clarify its role in PD and related disorders and the mechanism involved, genetic data, protein domains and structure, as well as functional studies were summarized when available. Although other genes had been related to this disease using Genome Wide Association Studies or other massive techniques, the lack of information about the genes or the lack of posterior confirmation or replication prevented us to deal with those proteins in this chapter.

Several pathways and cellular functions have been linked to PD, including mitochondrial dysfunction, oxidative stress, protein misfolding, ubiquitin-proteasome system alteration, autophagy, endosomal and lysosomal pathways, neurotransmitter metabolism, translation and cytoskeletal transport [110]. The mitochondrial dysfunction obviously affects the energy metabolism, but probably the main effect in the pathology is through the production of Reactive Oxygen Species (ROS), that are the main cause of oxidative stress [111]. The protein misfolding and chaperone functions are also important in the disease, since there are several chaperones among the proteins related to PD (chapters 2 and 10), and a well-known cause (or effect) of the disease is the formation of aggregates of misfolded proteins in the LB (chapters 1 and 10). Regarding these processes, the function of the protein degradation pathways (by the lysosome and 
the ubiquitin-proteasome system) are crucial for the clearance of these aggregates and misfolded proteins (chapters 2, 3, 6, 7 and 10). The endosomal and autophagic pathways are related to lysosomal function (Chapters 2, 4, 5, 8, 9 and 10), as well as neurotransmitter release and membrane protein internalization (for instance, receptors). A special type of autophagy (mitophagy) has been related to the disease recently, in particular to PINK1 and Parkin function (chapter 2).

According to the data available regarding its localization, function and pathways, the proteins involved in this disease could be grouped in four main pathways: Proteostasis (comprising protein misfolding, translation and degradation), Mitochondrion/oxidative stress, Neurotransmission and Vesicle traffic (Table 2). It is remarkably that some of the proteins described in this chapter are related to several, or even all, of these pathways (Figure 3).

In particular, according to its localization and function (Table 2) HTRA2, FBXO7 and DJ-1 are present in Proteostasis and Mitochondrion/oxidative groups (Table 2 and Figure 3) indicating that probably these proteins link these pathways in the explanation of the disease. It has been described that these three proteins are related to PINK1 and Parkin in the regulation of mitophagy (chapter 2). Thus, the importance of these proteins in PD pathogenesis probably could be attributed to this cellular process.

$\alpha$-synuclein and Parkin are found in three of the pathways (Table 2 and Figure 3 ). Their presence in most of the pathways points to the fact that these two proteins would play an important role in the pathology, in good agreement with what has also been suggested by other authors $[112,113]$. Also, the relation between these two proteins in the molecular events that occur in PD, including LB formation, is well known [114116]. It is also known the importance of the aggregation of $\alpha$-synuclein in oligomers and fibers, and the Parkin function promoting autophagic clearance of these aggregates [117].

LRRK2 and MAPT are present in all of the groups (Table 2 and Figure 3), pointing out a central role of these two proteins in the disease. It is well know the role of MAPT in neurodegenerative diseases that, similarly to $\alpha$-synuclein, produce aggregates as oligomers and tangles. The central role of MAPT is explained because axonal transport and cytoskeletal integrity are important for vesicle trafficking, mitochondrial transport and neurotransmission, therefore the cytoskeleton function must be right for optimal function of all the pathways. On its turn, LRRK2 has been proposed as a key regulator that links all the pathways in the disease (chapter 4), related to the fact that several functions have been proposed for this protein and this places it in all of the cellular pathways involved in PD. Also there are evidences that show that LRRK2 mutations affect pathways that involve other proteins implicated in the disease, specifically $\alpha$ synuclein and MAPT [118]. In addition, a connection is established between LRRK2 and MAPT [119] and $\alpha$-synuclein aggregation and clearance [120], as well as for the interaction of LRRK2 with $\alpha$-synuclein [119]. Also a role of $\alpha$-synuclein and LRRK2 
has been proposed in abnormal MAPT phosphorylation in pathological conditions [121]. 
Table 1. Parkinson's disease and related disorders related proteins

\begin{tabular}{|c|c|c|c|c|c|c|c|}
\hline locus & Protein & $\begin{array}{l}\text { Inheritance } \\
\text { - Onset }\end{array}$ & Function & Tissue & Localization & Pathology & $\begin{array}{l}\text { Animal } \\
\text { models }\end{array}$ \\
\hline PARK1 & $\alpha$-synuclein & AD-EO & membrane remodelling & $\begin{array}{l}\text { everywhere except } \\
\text { liver }\end{array}$ & $\begin{array}{l}\text { presynaptic terminals, } \\
\text { nucleus }\end{array}$ & $\begin{array}{l}\text { synucleinopathies } \\
\text { (PD, DLB, MSA) }\end{array}$ & ++ \\
\hline PARK2 & Parkin & AR-JO & E3 ubiquitin ligase & $\begin{array}{l}\text { Brain, heart, muscle, } \\
\text { testis }\end{array}$ & ubiquitous & PD & ++ \\
\hline PARK3 & SPR & AD-LO & sepiapterin reductase & everywhere & nucleus, cytoplasm & $\mathrm{DP}$ & + \\
\hline PARK5 & UCH-L1 & AD-LO & ubiquitin hidrolase & $\begin{array}{l}\text { Nervous system, } \\
\text { pancreas, kidney, } \\
\text { testis }\end{array}$ & $\begin{array}{l}\text { cytoplasm, nucleus, } \\
\text { endoplasmic reticulum }\end{array}$ & PD & + \\
\hline PARK6 & PINK1 & AR-EO & Ser/Thr kinase & everywhere & mitochondrial, cytoplasm & PD & + \\
\hline PARK7 & DJ-1 & AR-EO & Protein deglycase & everywhere & $\begin{array}{l}\text { cytoplasm, } \\
\text { mitochondrion, nucleus }\end{array}$ & PD & - \\
\hline PARK8 & LRRK2 & AD-LO & GTPase/kinase & everywhere & ubiquitous & PD & ++ \\
\hline PARK9 & ATP13A2 & AR-JO & ATPase & everywhere & lysosome (membrane) & Kufor-Rakeb syndrome & + \\
\hline PARK10 & $?$ & AD-LO & & & & & \\
\hline PARK11 & GIGYF2 & AD-LO & $\begin{array}{l}\text { signal transduction, translation } \\
\text { regulation }\end{array}$ & $\begin{array}{l}\text { Heart, liver, kidney, } \\
\text { brain, lung }\end{array}$ & $\begin{array}{l}\text { Cytoplasm, endosome, } \\
\text { membrane }\end{array}$ & PD & + \\
\hline PARK12 & ? & $\mathrm{XL-LO}$ & & & & $\mathrm{PD}$ & \\
\hline PARK13 & HTRA2 & AD-LO & protease & everywhere & mitochondrion (membrane) & PD & + \\
\hline PARK14 & PLA2G6 & AR-LO & phospholipase & everywhere & cytoplasm, membrane & $\mathrm{PD}$ & - \\
\hline PARK15 & FBXO7 & AR-LO & ubiquitin ligase complex & everywhere & $\begin{array}{l}\text { cytoplasm, } \\
\text { mitochondrion, nucleus }\end{array}$ & PD & \\
\hline PARK16 & RAB7L1 & AD-LO & Rab GTPase & everywhere & $\begin{array}{l}\text { cytoplasm, nucleus } \\
\text { (membrane) }\end{array}$ & PD & \\
\hline PARK17 & VPS35 & AD-LO & retromer component & everywhere & cytoplasm, vesicles & PD & \\
\hline PARK18 & EIF4G1 & AD-LO & translation regulation & everywhere & cytoplasm & PD & \\
\hline PARK19 & DNAJC6 & AR-JO & protein tyrosine phosphatase & Brain & cytoplasm, nucleus & PD & + \\
\hline PARK20 & SYNJ1 & AR-EO & $\begin{array}{l}\text { phosphatidylinositol } \\
\text { phosphatase }\end{array}$ & everywhere & cytoplasm & PD & + \\
\hline
\end{tabular}




\begin{tabular}{|c|c|c|c|c|c|c|c|}
\hline locus & Protein & $\begin{array}{l}\text { Inheritance } \\
\text { - Onset }\end{array}$ & Function & Tissue & Localization & Pathology & $\begin{array}{l}\text { Animal } \\
\text { models }\end{array}$ \\
\hline PARK21 & DNAJC13 & AD-LO & vesicle traffic & everywhere & cytoplasm, vesicles & PD & \\
\hline FTDP17 & MAPT & Risk factor & $\begin{array}{l}\text { microtubule assembly, } \\
\text { intracellular transport }\end{array}$ & Brain & cytoplasm, membrane & $\begin{array}{l}\text { Tauopathies (FTDP, PSP, } \\
\text { PiD, PD, AlzD) }\end{array}$ & + \\
\hline- & GBA & Risk factor & acid beta-glucocerebrosidase & everywhere & lysosome (membrane) & GD, PD & + \\
\hline
\end{tabular}

Inheritance: $A D=$ Autosomal Dominant; $A R=$ Autosomal Recessive; $X L=X$ linked. Onset: JO= Juvenile Onset; EO = Early Onset; $L O=$ Late Onset. Observed phenotypes for animal models (when exist) are labeled as "-" when no parkinsonian phenotype is observed, "+" for a phenotype that reminiscent of parkinsonism and "++" if phenotype closely resembles parkinsonism. PD = Parkinson Disease; DP= Dystonia with Parkinsonism; DLB = Dementia with Lewy Bodies; MSA= Multiple System Atrophy; PSP=

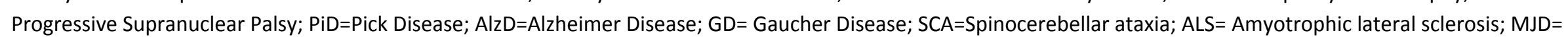
Machado-Joseph Disease.

Sources: Genecards (http://www.genecards.org/), The human protein atlas (http://www.proteinatlas.org/), OMIM (http://www.ncbi.nlm.nih.gov/omim) and Uniprot (http://www.uniprot.org/). 
Table 2. Proteins and pathways involved in Parkinson disease and related disorders. The proteins with functions described in these pathways are listed and coincident items are marked with grey background. Sources: Genecards (http://www.genecards.org/) and Uniprot (http://www.uniprot.org/)

\begin{tabular}{|c|c|c|c|}
\hline Proteostasis & $\begin{array}{l}\text { Mitochondrion/ } \\
\text { oxidative stress }\end{array}$ & Neurotransmision & Vesicle traffic \\
\hline LRRK2 & LRRK2 & LRRK2 & LRRK2 \\
\hline MAPT & MAPT & MAPT & MAPT \\
\hline & synuclein & synuclein & synuclein \\
\hline Parkin & Parkin & Parkin & \\
\hline HTRA2 & HTRA2 & SPR & VPS35 \\
\hline FBX07 & FBX07 & PLA2G6 & SYNJ1 \\
\hline DJ-1 & DJ-1 & NR4A2 & RAB7L1 \\
\hline DNAJC6 & PINK1 & & DNAJC6 \\
\hline GBA & & & GBA \\
\hline ATP13A2 & & & ATP13A2 \\
\hline EIF4G1 & & & GIGYF2 \\
\hline ATXN3 & & & DNAJC13 \\
\hline UCH-L1 & & & ATXN2 \\
\hline
\end{tabular}




\section{References}

1. Jankovic, J., Parkinson's disease: clinical features and diagnosis. Journal of neurology, neurosurgery, and psychiatry 2008, 79 (4), 368-76.

2. Russell, J. A.; Ciucci, M. R.; Connor, N. P.; Schallert, T., Targeted exercise therapy for voice and swallow in persons with Parkinson's disease. Brain research 2010, 1341, 3-11.

3. Barichella, M.; Cereda, E.; Pezzoli, G., Major nutritional issues in the management of Parkinson's disease. Movement disorders : official journal of the Movement Disorder Society 2009, 24 (13), 1881-92.

4. Armstrong, R. A., Visual signs and symptoms of Parkinson's disease. Clinical \& experimental optometry 2008, 91 (2), 129-38.

5. Bhidayasiri, R.; Reichmann, H., Different diagnostic criteria for Parkinson disease: what are the pitfalls? Journal of neural transmission 2013, 120 (4), 619-25.

6. GeneCards: The Human Gene Database. http://www.genecards.org/ (Accessed Nov 15, 2015).

7. The Human Protein Atlas. http://www.proteinatlas.org/ (Accessed Nov 15, 2015).

8. Online Mendelian Inheritance in Man (OMIM).

http://www.ncbi.nlm.nih.gov/omim (Accessed Nov 15, 2015).

9. UniProt Knowledgebase. http://www.uniprot.org/ (Accessed Nov 15, 2015).

10. Simon-Sanchez, J.; Singleton, A. B., Sequencing analysis of OMI/HTRA2 shows

previously reported pathogenic mutations in neurologically normal controls. Human molecular genetics 2008, 17 (13), 1988-93.

11. Gasser, T.; Muller-Myhsok, B.; Wszolek, Z. K.; Oehlmann, R.; Calne, D. B.; Bonifati, V.; Bereznai, B.; Fabrizio, E.; Vieregge, P.; Horstmann, R. D., A susceptibility locus for Parkinson's disease maps to chromosome 2p13. Nature genetics 1998, 18 (3), 262-5.

12. West, A. B.; Zimprich, A.; Lockhart, P. J.; Farrer, M.; Singleton, A.; Holtom, B.; Lincoln, S.; Hofer, A.; Hill, L.; Muller-Myhsok, B.; Wszolek, Z. K.; Hardy, J.; Gasser, T., Refinement of the PARK3 locus on chromosome $2 \mathrm{p} 13$ and the analysis of 14 candidate genes. European journal of human genetics : EJHG 2001, 9 (9), 659-66.

13. DeStefano, A. L.; Lew, M. F.; Golbe, L. I.; Mark, M. H.; Lazzarini, A. M.; Guttman, M.; Montgomery, E.; Waters, C. H.; Singer, C.; Watts, R. L.; Currie, L. J.; Wooten, G. F.; Maher, N. E.; Wilk, J. B.; Sullivan, K. M.; Slater, K. M.; Saint-Hilaire, M. H.; Feldman, R. G.; Suchowersky, O.; Lafontaine, A. L.; Labelle, N.; Growdon, J. H.; Vieregge, P.; Pramstaller, P. P.; Klein, C.; Hubble, J. P.; Reider, C. R.; Stacy, M.; MacDonald, M. E.; Gusella, J. F.; Myers, R. H., PARK3 influences age at onset in Parkinson disease: a genome scan in the GenePD study. American journal of human genetics 2002, 70 (5), 1089-95.

14. Karamohamed, S.; DeStefano, A. L.; Wilk, J. B.; Shoemaker, C. M.; Golbe, L. I.; Mark, M. H.; Lazzarini, A. M.; Suchowersky, O.; Labelle, N.; Guttman, M.; Currie, L. J.; Wooten, G. F.; Stacy, M.; Saint-Hilaire, M.; Feldman, R. G.; Sullivan, K. M.; Xu, G.; Watts, R.; Growdon, J.; Lew, M.; Waters, C.; Vieregge, P.; Pramstaller, P. P.; Klein, C.; Racette, B. A.; Perlmutter, J. S.; Parsian, A.; Singer, C.; Montgomery, E.; Baker, K.; Gusella, J. F.; Fink, S. J.; Myers, R. H.; Herbert, A.; Gene, P. D. S., A haplotype at the PARK3 locus influences onset age for Parkinson's disease: the GenePD study. Neurology 2003, 61 (11), 1557-61.

15. Sharma, M.; Mueller, J. C.; Zimprich, A.; Lichtner, P.; Hofer, A.; Leitner, P.; Maass, S.; Berg, D.; Durr, A.; Bonifati, V.; De Michele, G.; Oostra, B.; Brice, A.; Wood, N. W.; MullerMyhsok, B.; Gasser, T.; European Consortium on Genetic Susceptibility in Parkinson's, D., The sepiapterin reductase gene region reveals association in the PARK3 locus: analysis of familial and sporadic Parkinson's disease in European populations. Journal of medical genetics 2006, 43 (7), 557-62.

16. Bonafe, L.; Thony, B.; Penzien, J. M.; Czarnecki, B.; Blau, N., Mutations in the sepiapterin reductase gene cause a novel tetrahydrobiopterin-dependent monoamine- 
neurotransmitter deficiency without hyperphenylalaninemia. American journal of human genetics 2001, 69 (2), 269-77.

17. Steinberger, D.; Blau, N.; Goriuonov, D.; Bitsch, J.; Zuker, M.; Hummel, S.; Muller, U., Heterozygous mutation in 5 -untranslated region of sepiapterin reductase gene (SPR) in a patient with dopa-responsive dystonia. Neurogenetics 2004, 5 (3), 187-90.

18. Bikker, H.; Bakker, H. D.; Abeling, N. G.; Poll-The, B. T.; Kleijer, W. J.; Rosenblatt, D. S.; Waterham, H. R.; Wanders, R. J.; Duran, M., A homozygous nonsense mutation in the methylmalonyl-CoA epimerase gene (MCEE) results in mild methylmalonic aciduria. Human mutation 2006, 27 (7), 640-3.

19. Ponzone, A.; Porta, F.; Mussa, A.; Alluto, A.; Ferraris, S.; Spada, M., Unresponsiveness to tetrahydrobiopterin of phenylalanine hydroxylase deficiency. Metabolism: clinical and experimental 2010, 59 (5), 645-52.

20. CDD. NCBI's conserved domain database.

www.ncbi.nlm.nih.gov/Structure/cdd/wrpsb.cgi (Accessed Nov 15, 2015).

21. Yang, S.; Lee, Y. J.; Kim, J. M.; Park, S.; Peris, J.; Laipis, P.; Park, Y. S.; Chung, J. H.; Oh, S. P., A murine model for human sepiapterin-reductase deficiency. American journal of human genetics 2006, 78 (4), 575-87.

22. Lautier, C.; Goldwurm, S.; Durr, A.; Giovannone, B.; Tsiaras, W. G.; Pezzoli, G.; Brice, A.; Smith, R. J., Mutations in the GIGYF2 (TNRC15) gene at the PARK11 locus in familial Parkinson disease. American journal of human genetics 2008, 82 (4), 822-33.

23. Nichols, W. C.; Kissell, D. K.; Pankratz, N.; Pauciulo, M. W.; Elsaesser, V. E.; Clark, K. A.; Halter, C. A.; Rudolph, A.; Wojcieszek, J.; Pfeiffer, R. F.; Foroud, T.; Parkinson Study Group, P. I., Variation in GIGYF2 is not associated with Parkinson disease. Neurology 2009, 72 (22), 188692.

24. Zimprich, A.; Schulte, C.; Reinthaler, E.; Haubenberger, D.; Balzar, J.; Lichtner, P.; El Tawil, S.; Edris, S.; Foki, T.; Pirker, W.; Katzenschlager, R.; Daniel, G.; Brucke, T.; Auff, E.; Gasser, T., PARK11 gene (GIGYF2) variants Asn56Ser and Asn457Thr are not pathogenic for Parkinson's disease. Parkinsonism \& related disorders 2009, 15 (7), 532-4.

25. Bras, J.; Simon-Sanchez, J.; Federoff, M.; Morgadinho, A.; Januario, C.; Ribeiro, M.; Cunha, L.; Oliveira, C.; Singleton, A. B., Lack of replication of association between GIGYF2 variants and Parkinson disease. Human molecular genetics 2009, 18 (2), 341-6.

26. Guella, I.; Pistocchi, A.; Asselta, R.; Rimoldi, V.; Ghilardi, A.; Sironi, F.; Trotta, L.; Primignani, P.; Zini, M.; Zecchinelli, A.; Coviello, D.; Pezzoli, G.; Del Giacco, L.; Duga, S.; Goldwurm, S., Mutational screening and zebrafish functional analysis of GIGYF2 as a Parkinsondisease gene. Neurobiology of aging 2011, 32 (11), 1994-2005.

27. Tan, E. K.; Lin, C. H.; Tai, C. H.; Tan, L. C.; Chen, M. L.; Li, R.; Lim, H. Q.; Pavanni, R.; Yuen, Y.; Prakash, K. M.; Zhao, Y.; Wu, R. M., Non-synonymous GIGYF2 variants in Parkinson's disease from two Asian populations. Human genetics 2009, 126 (3), 425-30.

28. Ruiz-Martinez, J.; Krebs, C. E.; Makarov, V.; Gorostidi, A.; Marti-Masso, J. F.; PaisanRuiz, C., GIGYF2 mutation in late-onset Parkinson's disease with cognitive impairment. Journal of human genetics 2015.

29. Ash, M. R.; Faelber, K.; Kosslick, D.; Albert, G. I.; Roske, Y.; Kofler, M.; Schuemann, M.; Krause, E.; Freund, C., Conserved beta-hairpin recognition by the GYF domains of Smy 2 and GIGYF2 in mRNA surveillance and vesicular transport complexes. Structure 2010, 18 (8), $944-$ 54.

30. Higashi, S.; Iseki, E.; Minegishi, M.; Togo, T.; Kabuta, T.; Wada, K., GIGYF2 is present in endosomal compartments in the mammalian brains and enhances IGF-1-induced ERK1/2 activation. Journal of neurochemistry 2010, 115 (2), 423-37.

31. Giovannone, B.; Tsiaras, W. G.; de la Monte, S.; Klysik, J.; Lautier, C.; Karashchuk, G.; Goldwurm, S.; Smith, R. J., GIGYF2 gene disruption in mice results in neurodegeneration and altered insulin-like growth factor signaling. Human molecular genetics 2009, 18 (23), 4629-39. 
32. Wang, L.; Guo, J. F.; Zhang, W. W.; Xu, Q.; Zuo, X.; Shi, C. H.; Luo, L. Z.; Liu, J.; Hu, L.; Hu, Y. C.; Yan, X. X.; Tang, B. S., Follow-up study of variants of the GIGYF2 gene in Chinese patients with Parkinson's disease. Journal of clinical neuroscience : official journal of the Neurosurgical Society of Australasia 2011, 18 (12), 1699-701.

33. Zhang, Y.; Sun, Q. Y.; Yu, R. H.; Guo, J. F.; Tang, B. S.; Yan, X. X., The contribution of GIGYF2 to Parkinson's disease: a meta-analysis. Neurological sciences : official journal of the Italian Neurological Society and of the Italian Society of Clinical Neurophysiology 2015, 36 (11), 2073-9.

34. Gregory, A.; Westaway, S. K.; Holm, I. E.; Kotzbauer, P. T.; Hogarth, P.; Sonek, S.; Coryell, J. C.; Nguyen, T. M.; Nardocci, N.; Zorzi, G.; Rodriguez, D.; Desguerre, I.; Bertini, E.; Simonati, A.; Levinson, B.; Dias, C.; Barbot, C.; Carrilho, I.; Santos, M.; Malik, I.; Gitschier, J.; Hayflick, S. J., Neurodegeneration associated with genetic defects in phospholipase A(2). Neurology 2008, 71 (18), 1402-9.

35. Paisan-Ruiz, C.; Bhatia, K. P.; Li, A.; Hernandez, D.; Davis, M.; Wood, N. W.; Hardy, J.; Houlden, H.; Singleton, A.; Schneider, S. A., Characterization of PLA2G6 as a locus for dystoniaparkinsonism. Annals of neurology 2009, 65 (1), 19-23.

36. Yoshino, H.; Tomiyama, H.; Tachibana, N.; Ogaki, K.; Li, Y.; Funayama, M.; Hashimoto, T.; Takashima, S.; Hattori, N., Phenotypic spectrum of patients with PLA2G6 mutation and PARK14-linked parkinsonism. Neurology 2010, 75 (15), 1356-61.

37. Malaguti, M. C.; Melzi, V.; Di Giacopo, R.; Monfrini, E.; Di Biase, E.; Franco, G.; Borellini, L.; Trezzi, I.; Monzio Compagnoni, G.; Fortis, P.; Feraco, P.; Orrico, D.; Cucurachi, L.; Donner, D.; Rizzuti, M.; Ronchi, D.; Bonato, S.; Bresolin, N.; Corti, S.; Comi, G. P.; Di Fonzo, A., A novel homozygous PLA2G6 mutation causes dystonia-parkinsonism. Parkinsonism \& related disorders 2015, 21 (3), 337-9.

38. Shi, C. H.; Tang, B. S.; Wang, L.; Lv, Z. Y.; Wang, J.; Luo, L. Z.; Shen, L.; Jiang, H.; Yan, X. X.; Pan, Q.; Xia, K.; Guo, J. F., PLA2G6 gene mutation in autosomal recessive early-onset parkinsonism in a Chinese cohort. Neurology 2011, 77 (1), 75-81.

39. Engel, L. A.; Jing, Z.; O'Brien, D. E.; Sun, M.; Kotzbauer, P. T., Catalytic function of PLA2G6 is impaired by mutations associated with infantile neuroaxonal dystrophy but not dystonia-parkinsonism. PloS one 2010, 5 (9), e12897.

40. Xie, F.; Cen, Z.; Ouyang, Z.; Wu, S.; Xiao, J.; Luo, W., Homozygous p.D331Y mutation in PLA2G6 in two patients with pure autosomal-recessive early-onset parkinsonism: further evidence of a fourth phenotype of PLA2G6-associated neurodegeneration. Parkinsonism \& related disorders 2015, 21 (4), 420-2.

41. Forsell, P. K.; Lindberg, A.; Karlsson, S.; Lindgren, J. A.; Claesson, H. E., Purification, characterization, and cDNA sequencing of cytosolic phospholipase $A(2)$ from equine neutrophils. Journal of lipid research 2000, 41 (8), 1222-30.

42. PSI. The protein Model Portal. http://www.proteinmodelportal.org/ (Accessed Nov 15, 2015).

43. Malik, I.; Turk, J.; Mancuso, D. J.; Montier, L.; Wohltmann, M.; Wozniak, D. F.; Schmidt, R. E.; Gross, R. W.; Kotzbauer, P. T., Disrupted membrane homeostasis and accumulation of ubiquitinated proteins in a mouse model of infantile neuroaxonal dystrophy caused by PLA2G6 mutations. The American journal of pathology 2008, 172 (2), 406-16.

44. Sumi-Akamaru, H.; Beck, G.; Kato, S.; Mochizuki, H., Neuroaxonal dystrophy in PLA2G6 knockout mice. Neuropathology : official journal of the Japanese Society of Neuropathology 2015, 35 (3), 289-302.

45. Kinghorn, K. J.; Castillo-Quan, J. I.; Bartolome, F.; Angelova, P. R.; Li, L.; Pope, S.; Cocheme, H. M.; Khan, S.; Asghari, S.; Bhatia, K. P.; Hardy, J.; Abramov, A. Y.; Partridge, L., Loss of PLA2G6 leads to elevated mitochondrial lipid peroxidation and mitochondrial dysfunction. Brain : a journal of neurology 2015, 138 (Pt 7), 1801-16.

46. Chartier-Harlin, M. C.; Dachsel, J. C.; Vilarino-Guell, C.; Lincoln, S. J.; Lepretre, F.; Hulihan, M. M.; Kachergus, J.; Milnerwood, A. J.; Tapia, L.; Song, M. S.; Le Rhun, E.; Mutez, E.; 
Larvor, L.; Duflot, A.; Vanbesien-Mailliot, C.; Kreisler, A.; Ross, O. A.; Nishioka, K.; SotoOrtolaza, A. I.; Cobb, S. A.; Melrose, H. L.; Behrouz, B.; Keeling, B. H.; Bacon, J. A.; Hentati, E.; Williams, L.; Yanagiya, A.; Sonenberg, N.; Lockhart, P. J.; Zubair, A. C.; Uitti, R. J.; Aasly, J. O.; Krygowska-Wajs, A.; Opala, G.; Wszolek, Z. K.; Frigerio, R.; Maraganore, D. M.; Gosal, D.; Lynch, T.; Hutchinson, M.; Bentivoglio, A. R.; Valente, E. M.; Nichols, W. C.; Pankratz, N.; Foroud, T.; Gibson, R. A.; Hentati, F.; Dickson, D. W.; Destee, A.; Farrer, M. J., Translation initiator EIF4G1 mutations in familial Parkinson disease. American journal of human genetics 2011, 89 (3), 398406.

47. Nuytemans, K.; Bademci, G.; Inchausti, V.; Dressen, A.; Kinnamon, D. D.; Mehta, A.; Wang, L.; Zuchner, S.; Beecham, G. W.; Martin, E. R.; Scott, W. K.; Vance, J. M., Whole exome sequencing of rare variants in EIF4G1 and VPS35 in Parkinson disease. Neurology 2013, 80 (11), 982-9.

48. Nichols, N.; Bras, J. M.; Hernandez, D. G.; Jansen, I. E.; Lesage, S.; Lubbe, S.; Singleton, A. B.; International Parkinson's Disease Genomics, C., EIF4G1 mutations do not cause Parkinson's disease. Neurobiology of aging 2015, 36 (8), 2444 e1-4.

49. Yan, R.; Rhoads, R. E., Human protein synthesis initiation factor elF-4 gamma is encoded by a single gene (EIF4G) that maps to chromosome 3q27-qter. Genomics 1995, 26 (2), 394-8.

50. Imataka, H.; Sonenberg, N., Human eukaryotic translation initiation factor 4G (elF4G) possesses two separate and independent binding sites for elF4A. Molecular and cellular biology 1997, 17 (12), 6940-7.

51. Bellsolell, L.; Cho-Park, P. F.; Poulin, F.; Sonenberg, N.; Burley, S. K., Two structurally atypical HEAT domains in the C-terminal portion of human elF4G support binding to elF4A and Mnk1. Structure 2006, 14 (5), 913-23.

52. Schutz, P.; Bumann, M.; Oberholzer, A. E.; Bieniossek, C.; Trachsel, H.; Altmann, M.; Baumann, U., Crystal structure of the yeast elF4A-elF4G complex: an RNA-helicase controlled by protein-protein interactions. Proceedings of the National Academy of Sciences of the United States of America 2008, 105 (28), 9564-9.

53. Imataka, H.; Gradi, A.; Sonenberg, N., A newly identified N-terminal amino acid sequence of human elF4G binds poly(A)-binding protein and functions in poly(A)-dependent translation. The EMBO journal 1998, 17 (24), 7480-9.

54. Dhungel, N.; Eleuteri, S.; Li, L. B.; Kramer, N. J.; Chartron, J. W.; Spencer, B.; Kosberg, K.; Fields, J. A.; Stafa, K.; Adame, A.; Lashuel, H.; Frydman, J.; Shen, K.; Masliah, E.; Gitler, A. D., Parkinson's disease genes VPS35 and EIF4G1 interact genetically and converge on alphasynuclein. Neuron 2015, 85 (1), 76-87.

55. Karuppagounder, S. S.; Lee, Y.; Eacker, S. M.; Martin, I.; Kim, J.; Jia, H.; Brahmachari, S.; Kumar, M.; Mao, X.; Andrabi, S.; Swing, D.; Kang, S.; Jiang, H.; Tessarollo, L.; Dawson, T.; Dawson, V. L. In Transgenic mice overexpressing familial Parkinson's disease mutations in protein translation factor elF4G1 exhibit selective neurodegeneration of dopamine neurons, Neuroscience 2014. , Washington. USA, November 15-19, 2014.; Society for Neuroscience: Washington. USA, 2014.

56. Koroglu, C.; Baysal, L.; Cetinkaya, M.; Karasoy, H.; Tolun, A., DNAJC6 is responsible for juvenile parkinsonism with phenotypic variability. Parkinsonism \& related disorders 2013, 19 (3), 320-4.

57. Edvardson, S.; Cinnamon, Y.; Ta-Shma, A.; Shaag, A.; Yim, Y. I.; Zenvirt, S.; Jalas, C.; Lesage, S.; Brice, A.; Taraboulos, A.; Kaestner, K. H.; Greene, L. E.; Elpeleg, O., A deleterious mutation in DNAJC6 encoding the neuronal-specific clathrin-uncoating co-chaperone auxilin, is associated with juvenile parkinsonism. PloS one 2012, 7 (5), e36458.

58. Yim, Y. I.; Sun, T.; Wu, L. G.; Raimondi, A.; De Camilli, P.; Eisenberg, E.; Greene, L. E., Endocytosis and clathrin-uncoating defects at synapses of auxilin knockout mice. Proceedings of the National Academy of Sciences of the United States of America 2010, 107 (9), 4412-7. 
59. Hamza, T. H.; Zabetian, C. P.; Tenesa, A.; Laederach, A.; Montimurro, J.; Yearout, D.; Kay, D. M.; Doheny, K. F.; Paschall, J.; Pugh, E.; Kusel, V. I.; Collura, R.; Roberts, J.; Griffith, A.; Samii, A.; Scott, W. K.; Nutt, J.; Factor, S. A.; Payami, H., Common genetic variation in the HLA region is associated with late-onset sporadic Parkinson's disease. Nature genetics 2010, 42 (9), 781-5.

60. Simon-Sanchez, J.; van Hilten, J. J.; van de Warrenburg, B.; Post, B.; Berendse, H. W.; Arepalli, S.; Hernandez, D. G.; de Bie, R. M.; Velseboer, D.; Scheffer, H.; Bloem, B.; van Dijk, K. D.; Rivadeneira, F.; Hofman, A.; Uitterlinden, A. G.; Rizzu, P.; Bochdanovits, Z.; Singleton, A. B.; Heutink, P., Genome-wide association study confirms extant PD risk loci among the Dutch. European journal of human genetics : EJHG 2011, 19 (6), 655-61.

61. Nalls, M. A.; Pankratz, N.; Lill, C. M.; Do, C. B.; Hernandez, D. G.; Saad, M.; DeStefano, A. L.; Kara, E.; Bras, J.; Sharma, M.; Schulte, C.; Keller, M. F.; Arepalli, S.; Letson, C.; Edsall, C.; Stefansson, H.; Liu, X.; Pliner, H.; Lee, J. H.; Cheng, R.; International Parkinson's Disease Genomics, C.; Parkinson's Study Group Parkinson's Research: The Organized, G. I.; andMe; GenePd; NeuroGenetics Research, C.; Hussman Institute of Human, G.; Ashkenazi Jewish Dataset, I.; Cohorts for, H.; Aging Research in Genetic, E.; North American Brain Expression, C.; United Kingdom Brain Expression, C.; Greek Parkinson's Disease, C.; Alzheimer Genetic Analysis, G.; Ikram, M. A.; loannidis, J. P.; Hadjigeorgiou, G. M.; Bis, J. C.; Martinez, M.; Perlmutter, J. S.; Goate, A.; Marder, K.; Fiske, B.; Sutherland, M.; Xiromerisiou, G.; Myers, R. H.; Clark, L. N.; Stefansson, K.; Hardy, J. A.; Heutink, P.; Chen, H.; Wood, N. W.; Houlden, H.; Payami, H.; Brice, A.; Scott, W. K.; Gasser, T.; Bertram, L.; Eriksson, N.; Foroud, T.; Singleton, A. B., Large-scale meta-analysis of genome-wide association data identifies six new risk loci for Parkinson's disease. Nature genetics 2014, 46 (9), 989-93.

62. Beilina, A.; Rudenko, I. N.; Kaganovich, A.; Civiero, L.; Chau, H.; Kalia, S. K.; Kalia, L. V.; Lobbestael, E.; Chia, R.; Ndukwe, K.; Ding, J.; Nalls, M. A.; International Parkinson's Disease Genomics, C.; North American Brain Expression, C.; Olszewski, M.; Hauser, D. N.; Kumaran, R.; Lozano, A. M.; Baekelandt, V.; Greene, L. E.; Taymans, J. M.; Greggio, E.; Cookson, M. R., Unbiased screen for interactors of leucine-rich repeat kinase 2 supports a common pathway for sporadic and familial Parkinson disease. Proceedings of the National Academy of Sciences of the United States of America 2014, 111 (7), 2626-31.

63. Lee, J. O.; Yang, H.; Georgescu, M. M.; Di Cristofano, A.; Maehama, T.; Shi, Y.; Dixon, J. E.; Pandolfi, P.; Pavletich, N. P., Crystal structure of the PTEN tumor suppressor: implications for its phosphoinositide phosphatase activity and membrane association. Cell 1999, 99 (3), 323-34.

64. Fotin, A.; Cheng, Y.; Grigorieff, N.; Walz, T.; Harrison, S. C.; Kirchhausen, T., Structure of an auxilin-bound clathrin coat and its implications for the mechanism of uncoating. Nature 2004, 432 (7017), 649-53.

65. Qiu, X. B.; Shao, Y. M.; Miao, S.; Wang, L., The diversity of the DnaJ/Hsp40 family, the crucial partners for Hsp70 chaperones. Cellular and molecular life sciences : CMLS 2006, 63 (22), 2560-70.

66. Krebs, C. E.; Karkheiran, S.; Powell, J. C.; Cao, M.; Makarov, V.; Darvish, H.; Di Paolo, G.; Walker, R. H.; Shahidi, G. A.; Buxbaum, J. D.; De Camilli, P.; Yue, Z.; Paisan-Ruiz, C., The Sac1 domain of SYNJ1 identified mutated in a family with early-onset progressive Parkinsonism with generalized seizures. Human mutation 2013, 34 (9), 1200-7.

67. Quadri, M.; Fang, M.; Picillo, M.; Olgiati, S.; Breedveld, G. J.; Graafland, J.; Wu, B.; Xu, F.; Erro, R.; Amboni, M.; Pappata, S.; Quarantelli, M.; Annesi, G.; Quattrone, A.; Chien, H. F.; Barbosa, E. R.; International Parkinsonism Genetics, N.; Oostra, B. A.; Barone, P.; Wang, J.; Bonifati, V., Mutation in the SYNJ1 gene associated with autosomal recessive, early-onset Parkinsonism. Human mutation 2013, 34 (9), 1208-15.

68. Perera, R. M.; Zoncu, R.; Lucast, L.; De Camilli, P.; Toomre, D., Two synaptojanin 1 isoforms are recruited to clathrin-coated pits at different stages. Proceedings of the National Academy of Sciences of the United States of America 2006, 103 (51), 19332-7. 
69. Guo, S.; Stolz, L. E.; Lemrow, S. M.; York, J. D., SAC1-like domains of yeast SAC1, INP52, and INP53 and of human synaptojanin encode polyphosphoinositide phosphatases. The Journal of biological chemistry 1999, 274 (19), 12990-5.

70. Ha, S. A.; Torabinejad, J.; DeWald, D. B.; Wenk, M. R.; Lucast, L.; De Camilli, P.; Newitt, R. A.; Aebersold, R.; Nothwehr, S. F., The synaptojanin-like protein Inp53/Sjl3 functions with clathrin in a yeast TGN-to-endosome pathway distinct from the GGA protein-dependent pathway. Molecular biology of the cell 2003, 14 (4), 1319-33.

71. Voronov, S. V.; Frere, S. G.; Giovedi, S.; Pollina, E. A.; Borel, C.; Zhang, H.; Schmidt, C.; Akeson, E. C.; Wenk, M. R.; Cimasoni, L.; Arancio, O.; Davisson, M. T.; Antonarakis, S. E.; Gardiner, K.; De Camilli, P.; Di Paolo, G., Synaptojanin 1-linked phosphoinositide dyshomeostasis and cognitive deficits in mouse models of Down's syndrome. Proceedings of the National Academy of Sciences of the United States of America 2008, 105 (27), 9415-20. 72. Cremona, O.; Di Paolo, G.; Wenk, M. R.; Luthi, A.; Kim, W. T.; Takei, K.; Daniell, L.; Nemoto, Y.; Shears, S. B.; Flavell, R. A.; McCormick, D. A.; De Camilli, P., Essential role of phosphoinositide metabolism in synaptic vesicle recycling. Cell 1999, 99 (2), 179-88.

73. Vilarino-Guell, C.; Rajput, A.; Milnerwood, A. J.; Shah, B.; Szu-Tu, C.; Trinh, J.; Yu, I.; Encarnacion, M.; Munsie, L. N.; Tapia, L.; Gustavsson, E. K.; Chou, P.; Tatarnikov, I.; Evans, D. M.; Pishotta, F. T.; Volta, M.; Beccano-Kelly, D.; Thompson, C.; Lin, M. K.; Sherman, H. E.; Han, H. J.; Guenther, B. L.; Wasserman, W. W.; Bernard, V.; Ross, C. J.; Appel-Cresswell, S.; Stoessl, A. J.; Robinson, C. A.; Dickson, D. W.; Ross, O. A.; Wszolek, Z. K.; Aasly, J. O.; Wu, R. M.; Hentati, F.; Gibson, R. A.; McPherson, P. S.; Girard, M.; Rajput, M.; Rajput, A. H.; Farrer, M. J., DNAJC13 mutations in Parkinson disease. Human molecular genetics 2014, 23 (7), 1794-801.

74. Girard, M.; Poupon, V.; Blondeau, F.; McPherson, P. S., The DnaJ-domain protein RME8 functions in endosomal trafficking. The Journal of biological chemistry 2005, 280 (48), 4013543.

75. Volz, A.; Melkaoui, R.; Hildebrandt, F.; Omran, H., Candidate gene analysis of KIAA0678 encoding a DnaJ-like protein for adolescent nephronophthisis and Senior-Loken syndrome type 3. Cytogenetic and genome research 2002, 97 (3-4), 163-6.

76. Fujibayashi, A.; Taguchi, T.; Misaki, R.; Ohtani, M.; Dohmae, N.; Takio, K.; Yamada, M.; Gu, J.; Yamakami, M.; Fukuda, M.; Waguri, S.; Uchiyama, Y.; Yoshimori, T.; Sekiguchi, K., Human RME-8 is involved in membrane trafficking through early endosomes. Cell structure and function 2008, 33 (1), 35-50.

77. Sundaram, S. K.; Huq, A. M.; Sun, Z.; Yu, W.; Bennett, L.; Wilson, B. J.; Behen, M. E.; Chugani, H. T., Exome sequencing of a pedigree with Tourette syndrome or chronic tic disorder. Annals of neurology 2011, 69 (5), 901-4.

78. Li, Y. J.; Scott, W. K.; Hedges, D. J.; Zhang, F.; Gaskell, P. C.; Nance, M. A.; Watts, R. L.; Hubble, J. P.; Koller, W. C.; Pahwa, R.; Stern, M. B.; Hiner, B. C.; Jankovic, J.; Allen, F. A., Jr.; Goetz, C. G.; Mastaglia, F.; Stajich, J. M.; Gibson, R. A.; Middleton, L. T.; Saunders, A. M.; Scott, B. L.; Small, G. W.; Nicodemus, K. K.; Reed, A. D.; Schmechel, D. E.; Welsh-Bohmer, K. A.; Conneally, P. M.; Roses, A. D.; Gilbert, J. R.; Vance, J. M.; Haines, J. L.; Pericak-Vance, M. A., Age at onset in two common neurodegenerative diseases is genetically controlled. American journal of human genetics 2002, 70 (4), 985-93.

79. Hicks, A. A.; Petursson, H.; Jonsson, T.; Stefansson, H.; Johannsdottir, H. S.; Sainz, J.; Frigge, M. L.; Kong, A.; Gulcher, J. R.; Stefansson, K.; Sveinbjornsdottir, S., A susceptibility gene for late-onset idiopathic Parkinson's disease. Annals of neurology 2002, 52 (5), 549-55.

80. Oliveira, S. A.; Li, Y. J.; Noureddine, M. A.; Zuchner, S.; Qin, X.; Pericak-Vance, M. A.; Vance, J. M., Identification of risk and age-at-onset genes on chromosome 1p in Parkinson disease. American journal of human genetics 2005, 77 (2), 252-64.

81. Haugarvoll, K.; Toft, M.; Skipper, L.; Heckman, M. G.; Crook, J. E.; Soto, A.; Ross, O. A.; Hulihan, M. M.; Kachergus, J. M.; Sando, S. B.; White, L. R.; Lynch, T.; Gibson, J. M.; Uitti, R. J.; Wszolek, Z. K.; Aasly, J. O.; Farrer, M. J., Fine-mapping and candidate gene investigation within the PARK10 locus. European journal of human genetics: EJHG 2009, 17 (3), 336-43. 
82. Maraganore, D. M.; de Andrade, M.; Lesnick, T. G.; Strain, K. J.; Farrer, M. J.; Rocca, W. A.; Pant, P. V.; Frazer, K. A.; Cox, D. R.; Ballinger, D. G., High-resolution whole-genome association study of Parkinson disease. American journal of human genetics 2005, 77 (5), 685 93.

83. Noureddine, M. A.; Qin, X. J.; Oliveira, S. A.; Skelly, T. J.; van der Walt, J.; Hauser, M. A.; Pericak-Vance, M. A.; Vance, J. M.; Li, Y. J., Association between the neuron-specific RNAbinding protein ELAVL4 and Parkinson disease. Human genetics 2005, 117 (1), 27-33.

84. Haugarvoll, K.; Toft, M.; Ross, O. A.; Stone, J. T.; Heckman, M. G.; White, L. R.; Lynch, T.; Gibson, J. M.; Wszolek, Z. K.; Uitti, R. J.; Aasly, J. O.; Farrer, M. J., ELAVL4, PARK10, and the Celts. Movement disorders : official journal of the Movement Disorder Society 2007, 22 (4), 585-7.

85. DeStefano, A. L.; Latourelle, J.; Lew, M. F.; Suchowersky, O.; Klein, C.; Golbe, L. I.; Mark, M. H.; Growdon, J. H.; Wooten, G. F.; Watts, R.; Guttman, M.; Racette, B. A.; Perlmutter, J. S.; Marlor, L.; Shill, H. A.; Singer, C.; Goldwurm, S.; Pezzoli, G.; Saint-Hilaire, M. H.; Hendricks, A. E.; Gower, A.; Williamson, S.; Nagle, M. W.; Wilk, J. B.; Massood, T.; Huskey, K. W.; Baker, K. B.; Itin, I.; Litvan, I.; Nicholson, G.; Corbett, A.; Nance, M.; Drasby, E.; Isaacson, S.; Burn, D. J.; Chinnery, P. F.; Pramstaller, P. P.; Al-Hinti, J.; Moller, A. T.; Ostergaard, K.; Sherman, S. J.; Roxburgh, R.; Snow, B.; Slevin, J. T.; Cambi, F.; Gusella, J. F.; Myers, R. H., Replication of association between ELAVL4 and Parkinson disease: the GenePD study. Human genetics 2008, 124 (1), 95-9.

86. Wan, J. Y.; Edwards, K. L.; Hutter, C. M.; Mata, I. F.; Samii, A.; Roberts, J. W.; Agarwal, P.; Checkoway, H.; Farin, F. M.; Yearout, D.; Zabetian, C. P., Association mapping of the PARK10 region for Parkinson's disease susceptibility genes. Parkinsonism \& related disorders 2014, 20 (1), 93-8.

87. Satake, W.; Nakabayashi, Y.; Mizuta, I.; Hirota, Y.; Ito, C.; Kubo, M.; Kawaguchi, T.; Tsunoda, T.; Watanabe, M.; Takeda, A.; Tomiyama, H.; Nakashima, K.; Hasegawa, K.; Obata, F.; Yoshikawa, T.; Kawakami, H.; Sakoda, S.; Yamamoto, M.; Hattori, N.; Murata, M.; Nakamura, Y.; Toda, T., Genome-wide association study identifies common variants at four loci as genetic risk factors for Parkinson's disease. Nature genetics 2009, 41 (12), 1303-7.

88. Simon-Sanchez, J.; Schulte, C.; Bras, J. M.; Sharma, M.; Gibbs, J. R.; Berg, D.; PaisanRuiz, C.; Lichtner, P.; Scholz, S. W.; Hernandez, D. G.; Kruger, R.; Federoff, M.; Klein, C.; Goate, A.; Perlmutter, J.; Bonin, M.; Nalls, M. A.; Illig, T.; Gieger, C.; Houlden, H.; Steffens, M.; Okun, M. S.; Racette, B. A.; Cookson, M. R.; Foote, K. D.; Fernandez, H. H.; Traynor, B. J.; Schreiber, S.; Arepalli, S.; Zonozi, R.; Gwinn, K.; van der Brug, M.; Lopez, G.; Chanock, S. J.; Schatzkin, A.; Park, Y.; Hollenbeck, A.; Gao, J.; Huang, X.; Wood, N. W.; Lorenz, D.; Deuschl, G.; Chen, H.; Riess, O.; Hardy, J. A.; Singleton, A. B.; Gasser, T., Genome-wide association study reveals genetic risk underlying Parkinson's disease. Nature genetics 2009, 41 (12), 1308-12.

89. MacLeod, D. A.; Rhinn, H.; Kuwahara, T.; Zolin, A.; Di Paolo, G.; McCabe, B. D.; Marder, K. S.; Honig, L. S.; Clark, L. N.; Small, S. A.; Abeliovich, A., RAB7L1 interacts with LRRK2 to modify intraneuronal protein sorting and Parkinson's disease risk. Neuron 2013, 77 (3), 425-39. 90. Soto-Ortolaza, A. I.; Heckman, M. G.; Labbe, C.; Serie, D. J.; Puschmann, A.; Rayaprolu, S.; Strongosky, A.; Boczarska-Jedynak, M.; Opala, G.; Krygowska-Wajs, A.; Barcikowska, M.; Czyzewski, K.; Lynch, T.; Uitti, R. J.; Wszolek, Z. K.; Ross, O. A., GWAS risk factors in Parkinson's disease: LRRK2 coding variation and genetic interaction with PARK16. American journal of neurodegenerative disease 2013, 2 (4), 287-99.

91. Kolisek, M.; Sponder, G.; Mastrototaro, L.; Smorodchenko, A.; Launay, P.; Vormann, J.; Schweigel-Rontgen, M., Substitution p.A350V in $\mathrm{Na}(+) / \mathrm{Mg}(2)(+)$ exchanger SLC41A1, potentially associated with Parkinson's disease, is a gain-of-function mutation. PloS one 2013, $8(8)$, e71096.

92. Lin, C. H.; Wu, Y. R.; Chen, W. L.; Wang, H. C.; Lee, C. M.; Lee-Chen, G. J.; Chen, C. M., Variant $\mathrm{R} 244 \mathrm{H}$ in $\mathrm{Na}+\mathrm{Mg} 2+$ exchanger SLC41A1 in Taiwanese Parkinson's disease is associated with loss of Mg2+ efflux function. Parkinsonism \& related disorders 2014, 20 (6), 600-3. 
93. Goedert, M.; Spillantini, M. G.; Jakes, R.; Rutherford, D.; Crowther, R. A., Multiple isoforms of human microtubule-associated protein tau: sequences and localization in neurofibrillary tangles of Alzheimer's disease. Neuron 1989, 3 (4), 519-26.

94. Hutton, M.; Lendon, C. L.; Rizzu, P.; Baker, M.; Froelich, S.; Houlden, H.; PickeringBrown, S.; Chakraverty, S.; Isaacs, A.; Grover, A.; Hackett, J.; Adamson, J.; Lincoln, S.; Dickson, D.; Davies, P.; Petersen, R. C.; Stevens, M.; de Graaff, E.; Wauters, E.; van Baren, J.; Hillebrand, M.; Joosse, M.; Kwon, J. M.; Nowotny, P.; Che, L. K.; Norton, J.; Morris, J. C.; Reed, L. A.; Trojanowski, J.; Basun, H.; Lannfelt, L.; Neystat, M.; Fahn, S.; Dark, F.; Tannenberg, T.; Dodd, P. R.; Hayward, N.; Kwok, J. B.; Schofield, P. R.; Andreadis, A.; Snowden, J.; Craufurd, D.; Neary, D.; Owen, F.; Oostra, B. A.; Hardy, J.; Goate, A.; van Swieten, J.; Mann, D.; Lynch, T.; Heutink, P., Association of missense and 5 '-splice-site mutations in tau with the inherited dementia FTDP-17. Nature 1998, 393 (6686), 702-5.

95. Spillantini, M. G.; Murrell, J. R.; Goedert, M.; Farlow, M. R.; Klug, A.; Ghetti, B., Mutation in the tau gene in familial multiple system tauopathy with presenile dementia. Proceedings of the National Academy of Sciences of the United States of America 1998, 95 (13), 7737-41.

96. Panda, D.; Samuel, J. C.; Massie, M.; Feinstein, S. C.; Wilson, L., Differential regulation of microtubule dynamics by three- and four-repeat tau: implications for the onset of neurodegenerative disease. Proceedings of the National Academy of Sciences of the United States of America 2003, 100 (16), 9548-53.

97. Oliva, R.; Pastor, P., Tau gene delN296 mutation, Parkinson's disease, and atypical supranuclear palsy. Annals of neurology 2004, 55 (3), 448-9.

98. Rizzu, P.; Van Swieten, J. C.; Joosse, M.; Hasegawa, M.; Stevens, M.; Tibben, A.; Niermeijer, M. F.; Hillebrand, M.; Ravid, R.; Oostra, B. A.; Goedert, M.; van Duijn, C. M.; Heutink, P., High prevalence of mutations in the microtubule-associated protein tau in a population study of frontotemporal dementia in the Netherlands. American journal of human genetics 1999, 64 (2), 414-21.

99. Clark, L. N.; Poorkaj, P.; Wszolek, Z.; Geschwind, D. H.; Nasreddine, Z. S.; Miller, B.; Li, D.; Payami, H.; Awert, F.; Markopoulou, K.; Andreadis, A.; D'Souza, I.; Lee, V. M.; Reed, L.; Trojanowski, J. Q.; Zhukareva, V.; Bird, T.; Schellenberg, G.; Wilhelmsen, K. C., Pathogenic implications of mutations in the tau gene in pallido-ponto-nigral degeneration and related neurodegenerative disorders linked to chromosome 17. Proceedings of the National Academy of Sciences of the United States of America 1998, 95 (22), 13103-7.

100. Bugiani, O.; Murrell, J. R.; Giaccone, G.; Hasegawa, M.; Ghigo, G.; Tabaton, M.; Morbin, M.; Primavera, A.; Carella, F.; Solaro, C.; Grisoli, M.; Savoiardo, M.; Spillantini, M. G.; Tagliavini, F.; Goedert, M.; Ghetti, B., Frontotemporal dementia and corticobasal degeneration in a family with a P301S mutation in tau. Journal of neuropathology and experimental neurology 1999, 58 (6), 667-77.

101. Pastor, P.; Pastor, E.; Carnero, C.; Vela, R.; Garcia, T.; Amer, G.; Tolosa, E.; Oliva, R., Familial atypical progressive supranuclear palsy associated with homozigosity for the delN296 mutation in the tau gene. Annals of neurology 2001, 49 (2), 263-7.

102. Rossi, G.; Gasparoli, E.; Pasquali, C.; Di Fede, G.; Testa, D.; Albanese, A.; Bracco, F.; Tagliavini, F., Progressive supranuclear palsy and Parkinson's disease in a family with a new mutation in the tau gene. Annals of neurology 2004, 55 (3), 448.

103. Poorkaj, P.; Muma, N. A.; Zhukareva, V.; Cochran, E. J.; Shannon, K. M.; Hurtig, H.; Koller, W. C.; Bird, T. D.; Trojanowski, J. Q.; Lee, V. M.; Schellenberg, G. D., An R5L tau mutation in a subject with a progressive supranuclear palsy phenotype. Annals of neurology 2002, 52 (4), 511-6.

104. Hayashi, S.; Toyoshima, Y.; Hasegawa, M.; Umeda, Y.; Wakabayashi, K.; Tokiguchi, S.; Iwatsubo, T.; Takahashi, H., Late-onset frontotemporal dementia with a novel exon 1 (Arg5His) tau gene mutation. Annals of neurology 2002, 51 (4), 525-30. 
105. Giasson, B. I.; Forman, M. S.; Higuchi, M.; Golbe, L. I.; Graves, C. L.; Kotzbauer, P. T.; Trojanowski, J. Q.; Lee, V. M., Initiation and synergistic fibrillization of tau and alpha-synuclein. Science 2003, 300 (5619), 636-40.

106. Rizzu, P.; Hinkle, D. A.; Zhukareva, V.; Bonifati, V.; Severijnen, L. A.; Martinez, D.; Ravid, R.; Kamphorst, W.; Eberwine, J. H.; Lee, V. M.; Trojanowski, J. Q.; Heutink, P., DJ-1 colocalizes with tau inclusions: a link between parkinsonism and dementia. Annals of neurology 2004, 55 (1), 113-8.

107. de Calignon, A.; Fox, L. M.; Pitstick, R.; Carlson, G. A.; Bacskai, B. J.; Spires-Jones, T. L.; Hyman, B. T., Caspase activation precedes and leads to tangles. Nature 2010, 464 (7292), 12014.

108. Santacruz, K.; Lewis, J.; Spires, T.; Paulson, J.; Kotilinek, L.; Ingelsson, M.; Guimaraes, A.; DeTure, M.; Ramsden, M.; McGowan, E.; Forster, C.; Yue, M.; Orne, J.; Janus, C.; Mariash, A.; Kuskowski, M.; Hyman, B.; Hutton, M.; Ashe, K. H., Tau suppression in a neurodegenerative mouse model improves memory function. Science 2005, 309 (5733), 476-81.

109. Maraganore, D. M.; Hernandez, D. G.; Singleton, A. B.; Farrer, M. J.; McDonnell, S. K.; Hutton, M. L.; Hardy, J. A.; Rocca, W. A., Case-Control study of the extended tau gene haplotype in Parkinson's disease. Annals of neurology 2001, 50 (5), 658-61.

110. Trinh, J.; Farrer, M., Advances in the genetics of Parkinson disease. Nature reviews. Neurology 2013, 9 (8), 445-54.

111. Winklhofer, K. F.; Haass, C., Mitochondrial dysfunction in Parkinson's disease. Biochimica et biophysica acta 2010, 1802 (1), 29-44.

112. Kazantsev, A. G.; Kolchinsky, A. M., Central role of alpha-synuclein oligomers in neurodegeneration in Parkinson disease. Archives of neurology 2008, 65 (12), 1577-81.

113. Dawson, T. M.; Dawson, V. L., The role of parkin in familial and sporadic Parkinson's disease. Movement disorders : official journal of the Movement Disorder Society 2010, 25 Suppl 1, S32-9.

114. Shimura, H.; Schlossmacher, M. G.; Hattori, N.; Frosch, M. P.; Trockenbacher, A.; Schneider, R.; Mizuno, Y.; Kosik, K. S.; Selkoe, D. J., Ubiquitination of a new form of alphasynuclein by parkin from human brain: implications for Parkinson's disease. Science 2001, 293 (5528), 263-9.

115. Chung, K. K.; Zhang, Y.; Lim, K. L.; Tanaka, Y.; Huang, H.; Gao, J.; Ross, C. A.; Dawson, V. L.; Dawson, T. M., Parkin ubiquitinates the alpha-synuclein-interacting protein, synphilin-1: implications for Lewy-body formation in Parkinson disease. Nature medicine 2001, 7 (10), 1144-50.

116. Norris, K. L.; Hao, R.; Chen, L. F.; Lai, C. H.; Kapur, M.; Shaughnessy, P. J.; Chou, D.; Yan, J.; Taylor, J. P.; Engelender, S.; West, A. E.; Lim, K. L.; Yao, T. P., Convergence of Parkin, PINK1, and alpha-Synuclein on Stress-induced Mitochondrial Morphological Remodeling. The Journal of biological chemistry 2015, 290 (22), 13862-74.

117. Lonskaya, I.; Desforges, N. M.; Hebron, M. L.; Moussa, C. E., Ubiquitination increases parkin activity to promote autophagic alpha-synuclein clearance. PloS one 2013, 8 (12), e83914.

118. Cookson, M. R., The role of leucine-rich repeat kinase 2 (LRRK2) in Parkinson's disease. Nature reviews. Neuroscience 2010, 11 (12), 791-7.

119. Guerreiro, P. S.; Gerhardt, E.; Lopes da Fonseca, T.; Bahr, M.; Outeiro, T. F.; Eckermann, K., LRRK2 Promotes Tau Accumulation, Aggregation and Release. Molecular neurobiology 2015. 120. Mamais, A.; Raja, M.; Manzoni, C.; Dihanich, S.; Lees, A.; Moore, D.; Lewis, P. A.; Bandopadhyay, R., Divergent alpha-synuclein solubility and aggregation properties in G2019S LRRK2 Parkinson's disease brains with Lewy Body pathology compared to idiopathic cases. Neurobiology of disease 2013, 58, 183-90.

121. Kawakami, F.; Ichikawa, T., The Role of alpha-Synuclein and LRRK2 in Tau Phosphorylation. Parkinson's disease 2015, 2015, 734746. 


\section{Figure legends}

Figure 1. Domain architecture of several proteins involved in Parkinson disease. The boundaries of the domains and the position of the mutations described are showed. Abbreviations referring to domains with an assigned function are described in the text. Domain description: SPR-like SDRc= Sepiapterin reductase, GYF= Smy2-type GlyTyr-Phe, Patatin-like= Patatin-like phospholipase, Med15= co-activator of the transcription factor SREBP, Mif4G= eIF4A-binding domain, MA3= eIF3-binding region, $\mathrm{W} 2=$ binding site for eIF4E, PtenC2= membrane binding, Dnaj= interaction with Hsp70, Syja N= PI-phosphatase, INPP5c= inositol polyphosphate 5-phosphatase, $\mathrm{RRM}=\mathrm{RNA}$-binding domain, $\mathrm{ANK}=$ Ankyrin-repeats. For domains of unknown function we used: 1777= DUF1777; PTZ00249= variable surface protein Vir28; 4339= DUFF4339.

Figure 2. Domain architecture of the isoforms of MAPT showing the presence or absence of the R3, N1 and N2 domains. The boundaries of the domains and the position of the mutations described are showed for the larger isoform (4RN2).

Figure 3. Venn diagrams for the 4 groups of cellular functions established for PD. The proteins are grouped according to table 2, but only the proteins present in several groups are showed.

Supplementary Figure 1. Alignment of the central region of GIGYF2 in the chordate phylum. Totally conserved residues are in black background, high conserved residues in dark grey and partially conserved residues in light grey. Note the high conservation of the GYF domain (residues 533 to 669).

Supplementary Figure 2. Structural model of the effects of the mutation p.D331Y of PLA2G6 in the electrostatic surface. The secondary structure (ribbons) and the electrostatic surface of the frontal and lateral views of the Ankyrin domain are shown. The residue mutated is marked by chemist structure of the amino acid (ribbons) or by an arrow (electrostatic surface). 
GIGYF2

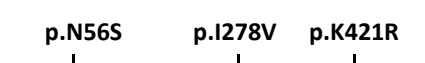

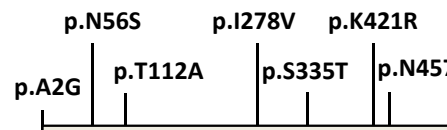

p.D606E 1920

\section{PLA2G6}

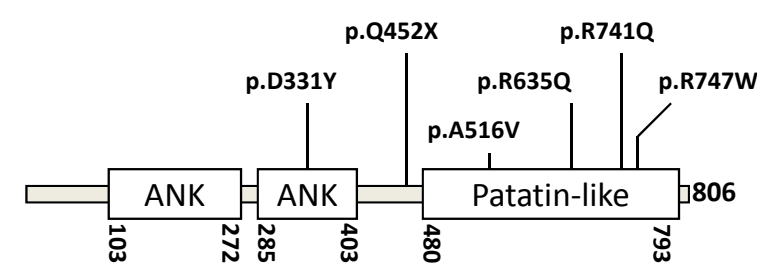

EIF4G1

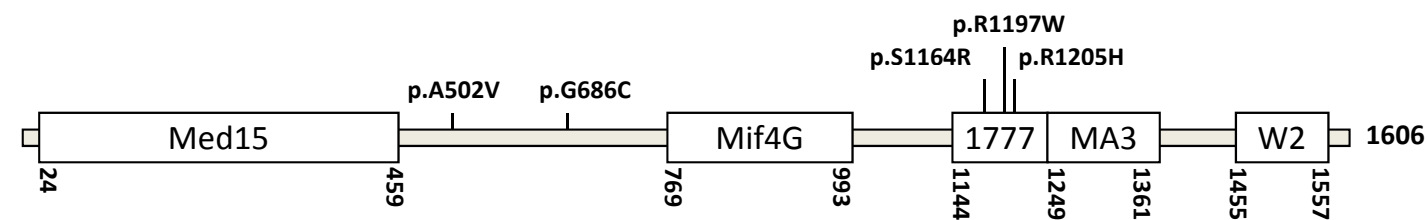

DNAJC6

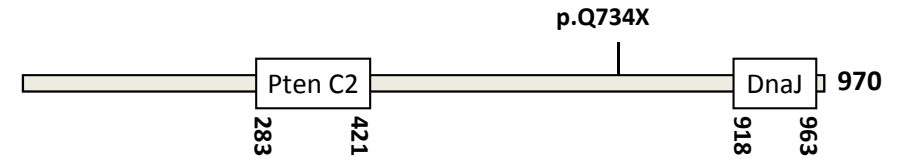

SYNJ1

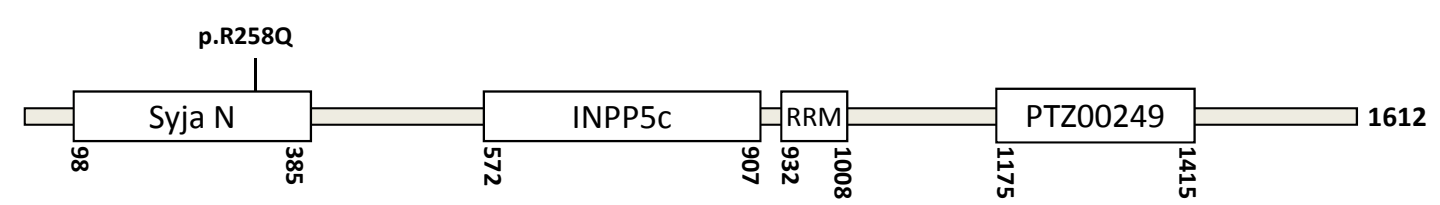

DNAJC13

(1).N855s




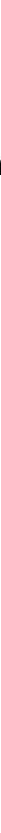



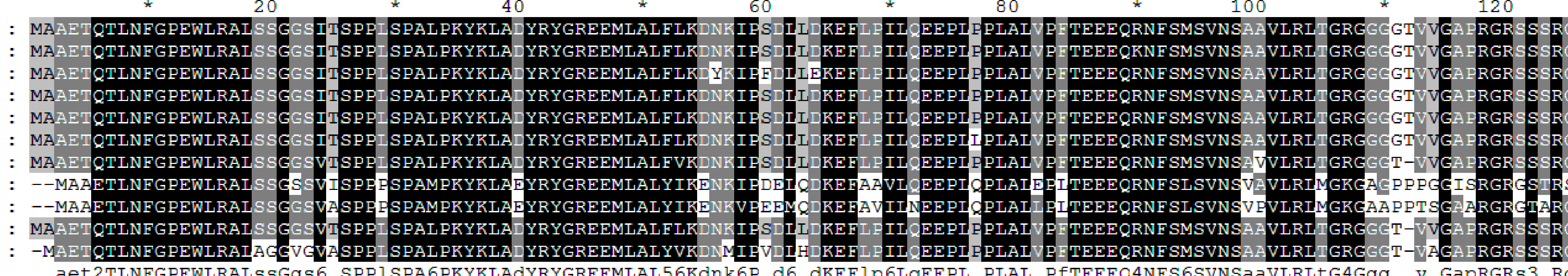
"IIII
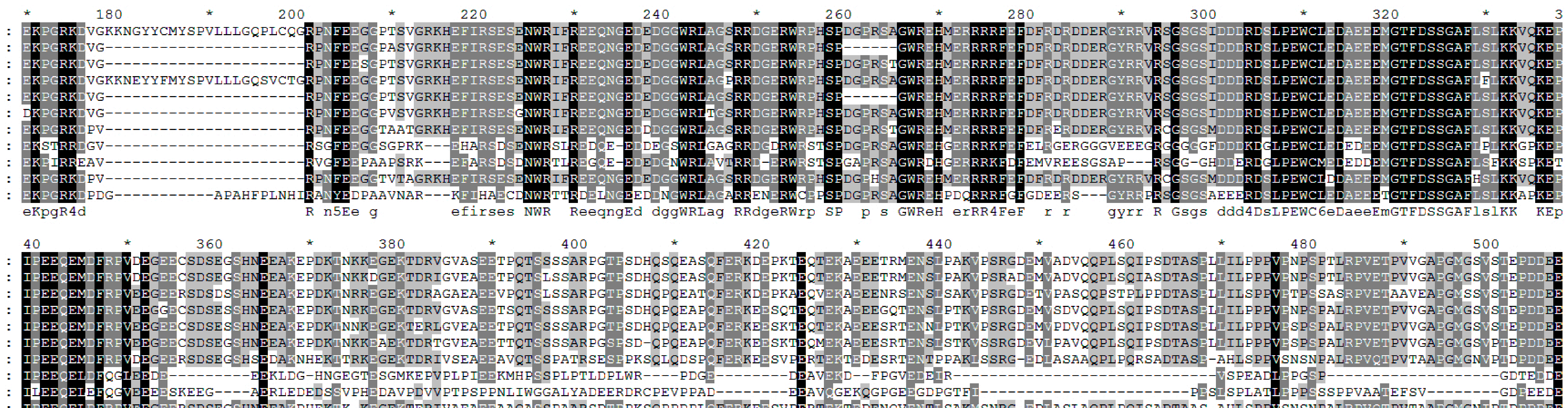

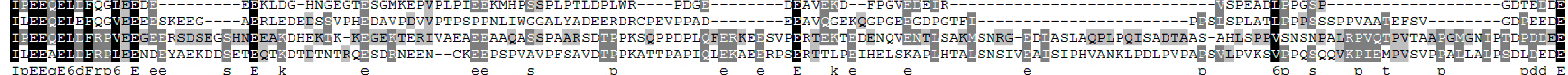


Suppl.

Fig. 1 
